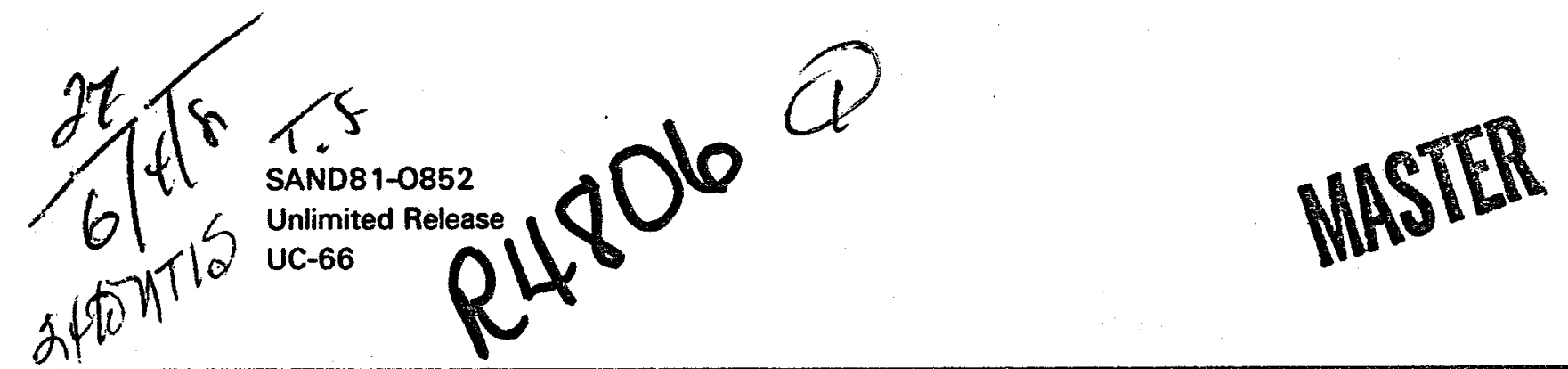

\title{
Geothermal Studies at Kirtland Air Force Base, Albuquerque, New Mexico
}

Linda Riddle, Bob Grant

\section{(1i) Sandia National Laboratories}




\section{DISCLAIMER}

This report was prepared as an account of work sponsored by an agency of the United States Government. Neither the United States Government nor any agency Thereof, nor any of their employees, makes any warranty, express or implied, or assumes any legal liability or responsibility for the accuracy, completeness, or usefulness of any information, apparatus, product, or process disclosed, or represents that its use would not infringe privately owned rights. Reference herein to any specific commercial product, process, or service by trade name, trademark, manufacturer, or otherwise does not necessarily constitute or imply its endorsement, recommendation, or favoring by the United States Government or any agency thereof. The views and opinions of authors expressed herein do not necessarily state or reflect those of the United States Government or any agency thereof. 


\section{DISCLAIMER}

Portions of this document may be illegible in electronic image products. Images are produced from the best available original document. 
Issued by Sandia National Laboratorfes, operated for the United States Department of Energy by Sandia Corporation.

NOTICE: This report was prepared as an account of work sponsored by an agency of the United States Government. Neither the United States Government nor any agency thereof. nor any of their employees, nor any of their contractors, subcontractors, or their responsibit for the accurranty express or implied, or assumes any legal aporatus product, or process disclosed, or represents that its use would not infringe privately owned rights. Reference herein to any specific commercial product, process, or service by trade name, trademark, manufacturer, or otherwise, does not necessarily constitute or imply its endorsement. recommendation, or favoring by the United States Government any agency thereol or any of their contractors or subcontractors. The views and opinions expressed herein do not necessarly state or reflect those of the United States Government, any agency thereof or any of their contractors or subcontractors.

- 


\title{
GEOTHERMAL STUDIES AT RIRTLAND AIR FORCE BASE ALBUQUERQUE, NEW MEXICO
}

\author{
Linda Riddle \\ Sandia National Laboratories \\ Geothermal Research Division 4743 \\ Albuquerque, NM 87185 \\ Bob Grant \\ Energy Resources Exploration, Inc. \\ Albuquerque, NM 87112
}

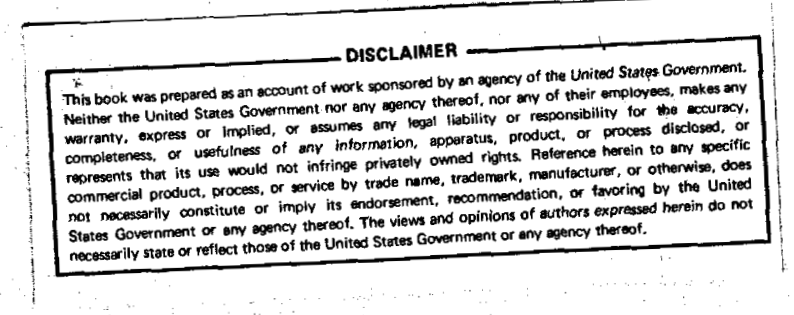

\section{ABSTRACT}

Due to an effort by government installations to discontinue use of natural gas, alternative energy sources are being lnvest1gated at Rirtland Alr Force Base, Albuquerque, New Mexico. New Mexico has geologic characteristics: favorable for geothermal energy utilization. Local heat flow and geochemical studies indicate a normal subsurface temperature regime. The alluvial deposits, however, extend to great depths where hot fluids, heated by the normal geothermal gradient, could be encountered. 


\section{(A) 4 CQNTENTS}

Introduction

Research Program

K1rtland Exploration Program

Geologic Setting

Hydrology

Heat Flow

16

Geophysics

21

Geochemistry and Geothermometry

Summary af Results

Basin Model

Fault Model

APPENDIX A-Use of CSAMT Technique to Map

Figure

\section{LIST OF ILLUSTRATIONS}

1 Generalized Section of Geologic Formations in the Albuquerque Area, Bernalillo and Sandoval Counties, New Mexico

2 Groundwater Units in the Albuquerque-Belen Basin (Kelly, 1974).

3 Location, Depth and Bottom Hole Temperature of Local Wells

4 Heat Flow Map of New Mexico and Colorado (Reiter et al, 1979)

5 Temperature Gradlents at Albuquerque, New Mexico (Parker and Jiracek, 1980)

6 Bouger Gravity Map of Albuquerque-Belen Basin (Cordell, 1973)

7 Cross Section of Albuquerque-Belen Basin (Birch, 1980)

8 Location of Springs and Wells 28

9 Ratio of Deuterium to 18 o Concentration for 32 Spring Water Samples 


\section{LIST OF ILLUSTRATIONS (cont'd)}

Figure

Page

10. Cross Section Showing Basin and Fault Model

A-1 CSAMT Geometry

A-2 Location of Transmitter and Survey Iines, Depth to Granite Indicated Fig. A-2

A-4 Apparent Resistivity Contours for survey Line in F1g. A-2

Table

1 Chemical Analyses from the Kirtland Air Force Base Area

2 Subsurface Temperature Calculations from

31 Geothermometers 


\section{GEOTHERMAL STUDIES AT KIRTLAND AIR FORCE BASE ALBUQUERQUE, NEW MEXICO}

\section{Introduction}

New Mexico is a hot spot for geothermal energy. New Mexico Energy and Minerals Department estimates the state's geothermal potential of up to $3500 \mathrm{MW}$ electrical and 2500 trillion Btu of direct use applications (Geothermal Report, 1980) . Elght sites in the state have been designated by the United states Geological survey as "known geothermal resource areas" (KGRA's). Two of these areas are being developed. Union oll company of California has plans for a $50 \mathrm{MW}$ power plant in the Jemez Mountains and New Mexico state University is successfully using geothermal sources for space heating at Las Cruces. Exploration at other sites is continuing through commercial interests and also through funding by the New Mexico Energy Institute. In addition to the known areas, New Mexico's geologic conditions are favorable for geothermal activity which has no obvious surface manifestation. Recent faulting along the Rio Grande Rift associated with young volcanic deposits, high heat flow and an anomalous crustal zone, are all positive factors. The basins of the rift are quite deep and may supply sufficlent water at high temperatures.

The Kirtland AIr Force Base is situated along the edge of the Rio Grande Rift and is in the deepest of the rift basins. The local area also has recent volcanic deposits and extensive faulting. 


\section{Research Program}

Exploring for geothermal resources requires the collection and integration of a variety of information. This information ranges from the requirements of the user to the detalls of the subsurface geology. A well-organized exploration program should minimize the cost of a preliminary study and have the flexibility to change direction or terminate as the data warrant. Most important is that the data collected form an integrated base of knowledge from which conclusions can be drawn. These requirements necessitate a step-by-step approach so that the data at each step are evaluated and decisions are made either to end the study or to continue. A typical program will include an information search, geological, hydrological, geophysical, and geochemical investigations, exploratory drilling, and, if all goes well, developmental drilling. The program at kirtland Base is outlined below. This report contains information gathered from the library search and from studies conducted as a result of this exploration program.

\section{Kirtland Exploration Program}

I. Literature Search
A. Geothermal Studies
B. Geology
C. Hydrology
D. Geochemistry
E. Geophysical studies 
II. Hydrologic study
A. Data Acquisition
B. Analysis

III. Geochemical Sampling
A. Spring selection
B. Sampling
c. Analysis

IV. Geophysical study--audio magnetoteliuric
A. Site selection
B. Data collection
C. Analysis

Geologic setting

The Kirtland Air Force Base is located along the far eastern margin of the Rio Grande rift in the Albuquerque-Belen Basin. The rift is characterized by recent extensional faulting, high heat flow, crustal and mantle anomalies, and young volcanic activity. Six structural basins arranged in a step pattern make up the rift zone which extends from Leadvilie, Colorado to EI Paso, Texas (Chapin, 1971). The Albuquerque-Belen Basin is in the central rift area and is the largest and deepest of the basins (Relley, 1977). The basin is belleved to have a horst-andgraben structure allowing subsidence of the central graben along a series of normal faults. The basin $1 \mathrm{~s}$ asymmetrical, with the east boundary dipping more steeply than the west. The east and south portions of the basin are the deepest. Unconsolidated to moderately consolidated sand and gravel (valley fill) fill the basin. This material was derived from the adjacent highlands 
during erosion. The thickness of the fill varies from thin at the margins to thick in the center. A cross section through the rift shown in Figure I lilustrates these characteristics. The maximum thickness of the fill is unknown, however, the Shell Isleta well \#2 possibly remained in the sediments down to 22,000 feet.

The geology on the Rirtland Base has been studied by Relley and Northrup (1975), KeIley (1977), Relche (1949), and Myers and McKay $(1970,1976)$. We field checked their work and summarized the geology as shown in Plate 1 . Outcrops occur in the eastern half of the base area and alluvium covers the western half. Several faults cross the area; especlally notable are the Tijeras fault and the Hubbell springs fault. The Tijeras fault zone is a major structural feature that extends for miles to the northeast. Th1s zone has had recurrent movement since the Precambrian and may represent a weakness in the crystalline basement (Kelley, 1977). The Tijeras fault outcrops in a large road cut on the Manzano Base and in a small mound to the southwest. Its southwest continuation is uncertain, as it disappears under the alluvium. The Hubbeli springs fault has a north-south trend and may be a primary rift fault. This fault is represented by a fault scarp on the Isleta Indian property south of Rirtland. Here, Permlan beds are exposed. The northern continuation of this fault has not been confirmed, although kelley and others suggest its presence west of the Manzano base. These two faults divide the base into at least 3 provinces. North of the Tijeras fault the geologic character is similar to the sandia uplift. 


\begin{tabular}{|c|c|c|c|c|c|c|}
\hline ERA & BYSTEM & SEAIES & UNIT & $\begin{array}{c}\text { THICKMESS } \\
\text { (FEET) }\end{array}$ & LITHOLOAY & WATER-BEAGINO CHARACTERIBTICS \\
\hline \multirow{5}{*}{ 足 } & \multirow[t]{3}{*}{ OUATERMAAY } & \multirow[t]{2}{*}{ RECENT } & ALUVIUM & O то $120 \pm$ & $\begin{array}{l}\text { COBBLES, GRAYEL, SANO, BILT, AND CLAY; } \\
\text { UWCONBOLIDATED. OEMEMALIY UNDERLIES } \\
\text { YALLEY FLOOA. }\end{array}$ & $\begin{array}{l}\text { YIELDS LARGE OUANTITIES OF WATEA OF } 6000 \text { TO } \\
\text { FAIR QUALITY TO IRRIOATION, INDUSTRIAL. } \\
\text { STOCK, AND DOMESTIC WELLS. WATEA GEMERALLY } \\
\text { HAS A HIOH SILICA CONTENT. }\end{array}$ \\
\hline & & & $\begin{array}{l}\text { DAJADA } \\
\text { DEPOSITS }\end{array}$ & - ro $200 \pm$ & $\begin{array}{l}\text { BOULDEAS, COBSLES, GAAVEL, SAND, AND BILT. } \\
\text { CONSISTING OF FRAGMENTS OF FELDSPAR, } \\
\text { QUART2, AND IGNEOUS ANO METAMONPHIC } \\
\text { ROCKS; UNCONBOLIDATED TO LOOSELY } \\
\text { COMSOLIDATED. }\end{array}$ & $\begin{array}{l}\text { OENERALLY LIE ABOVE THE WATER TABLE EXCEPT } \\
\text { ALONG THE MOUNTAIN FHONT AT THE CONTACT } \\
\text { WITH PRE-TERTIAGY ROCKS. VIELD SOME WATER } \\
\text { TO CONTACT SPAINGS AND WAY VIELD WATER TO } \\
\text { A FEW DOMESTIC AND STOCK WELLS. }\end{array}$ \\
\hline & & $\begin{array}{l}\text { PLEIBTOCENE } \\
\text { (?) }- \text { MOCENE (1) }\end{array}$ & $\begin{array}{l}\text { SANTA FE } \\
\text { GROUP }\end{array}$ & $\begin{array}{l}0.10 \\
0,100+ \\
0.100\end{array}$ & $\begin{array}{l}\text { DOULDEAS, COBBLES, CA AYEL, SAND, BLT, AND } \\
\text { CLAY; UNCONSOLIDATED TO CONSOLIDATEO BUT } \\
\text { GENERALLY WEAKLY CEMENTED. INCLUDES } \\
\text { INTEREEDDED VOLCANIC MATERIAL LOCALYY }\end{array}$ & $\begin{array}{l}\text { YIELOS LAMOE QUANTITIES OF WATEN OF OOOD } \\
\text { OUALITY TO MUNICIPAL, INOUSTRIAL, IRAIOA- } \\
\text { TION, BTOCK, AND DOMESTIC WELLS. WATER } \\
\text { GEMERALLY HAS A HIOH SILICA CONTENT. }\end{array}$ \\
\hline & \multirow{2}{*}{ TERTIAAY } & EOCENE & $\begin{array}{l}\text { ESPINASO } \\
\text { VOLCANIC } \\
\text { ROCKS OF } \\
\text { STEANNS } \\
(1043)\end{array}$ & $\begin{array}{l}100 \mathrm{TO} \\
1,400\end{array}$ & IAECCIA, CONOLOMERATE, AND TUFF. & $\begin{array}{l}\text { DEEPLY OUAIEO IF PHESENT; NO WELLS } \\
\text { ARE KNOWM TO BE COMPLETED IM THIS FORMA TION. }\end{array}$ \\
\hline & & $\begin{array}{l}\text { EOCENE AND } \\
\text { OLIGOCENE ( } 7)\end{array}$ & $\begin{array}{l}\text { QALISTEO } \\
\text { FOAMATION }\end{array}$ & $\begin{array}{l}900 \text { To } \\
4,000\end{array}$ & SANDSTONE, BAND, CLAY, AND SHALE. & Do. \\
\hline \multirow{9}{*}{ 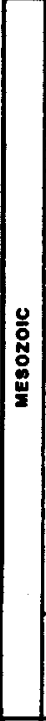 } & \multirow[t]{3}{*}{ CAETACEOUS } & \multirow[t]{3}{*}{ UPPEA } & $\begin{array}{l}\text { MESAYEADE } \\
\text { GAOUP }\end{array}$ & $\begin{array}{l}1,800 \text { To } \\
2,000\end{array}$ & $\begin{array}{l}\text { PAEDOMINANTLY ORAY TO ELACK SHALE, } \\
\text { IMCLUDES SEVERAL PROMINENT EEDS OF EUFF- } \\
\text { COLORED TO GAAY SANDSTONE AND GOME THIN } \\
\text { BEDS OF COAL. }\end{array}$ & $\begin{array}{l}\text { NO WELLS TAP THIS UNIT SECAUSE OF OREAT } \\
\text { DEPTH. SANOSTONE EEOS YELD WATER OF FAIA } \\
\text { TO POOR QUALITY TO STOCK ANO DOMESTIC } \\
\text { WELLS IN ADJOINING AREAS. }\end{array}$ \\
\hline & & & $\begin{array}{l}\text { MANCOS } \\
\text { BHALE }\end{array}$ & $\begin{array}{l}100 \text { To } \\
2,600\end{array}$ & $\begin{array}{l}\text { PREDOMINENTLY GRAY TO ELACK SHALE; } \\
\text { INCLUOES SEVERAL BEDS OF BUFF-COLORED } \\
\text { TO GAAY SAROSTONE. }\end{array}$ & Do. \\
\hline & & & $\begin{array}{l}\text { DAKOTA } \\
\text { SANOSTONE }\end{array}$ & $7870+10$ & $\begin{array}{l}\text { BAKDSTONE, BUFF TO TAN; INTENBEDDED } \\
\text { SHALE. }\end{array}$ & Do. \\
\hline & \multirow[t]{5}{*}{ JURASSIC } & \multirow[t]{5}{*}{ UPPER } & $\begin{array}{l}\text { MORAISON } \\
\text { FORMATION }\end{array}$ & $\begin{array}{l}210 \text { To } \\
660\end{array}$ & $\begin{array}{l}\text { BHALE, GREEN, PINK, ORAY, AND MAROON, } \\
\text { ANO WHITE ANO BUFF SAMOSTONE MEMBERS. }\end{array}$ & Do. \\
\hline & & & \begin{tabular}{|l|l|} 
BUFF \\
SANDSTONEE \\
\end{tabular} & $\begin{array}{l}100 \mathrm{TO} \\
140\end{array}$ & SAMDSTONE, DUFF. & Do. \\
\hline & & & $\begin{array}{l}\text { SUMWERYILLE } \\
\text { FOAMATION }\end{array}$ & 60 to 120 & SAMDSTONE AND SAMOY SHALE, GED TO GRAY. & Do. \\
\hline & & & $\begin{array}{l}\text { TODILTO } \\
\text { LIMESTONE } \\
\end{array}$ & 40 TO 260 & $\begin{array}{l}\text { TWO EEDS OF LIMESTONE OEPARATED EY A } \\
\text { THICK DED OF OYPBUM. }\end{array}$ & $\begin{array}{l}\text { GURIED DEEPLY; YIELDS LITTLE OA WO WATER. } \\
\text { WATER HAS A HIGH SULFATE CONTENT. }\end{array}$ \\
\hline & & & $\begin{array}{l}\text { ENTAADA } \\
\text { BANDSTONE }\end{array}$ & $\begin{array}{l}180 \text { ro } \\
220\end{array}$ & SANDSTONE, C'ROSS-SEDDED, RED TO GRAY. & $\begin{array}{l}\text { BUAIED DEEPLY: YIELDS WATER TO STOCK AND } \\
\text { DOMESTIC WELLS WN ADJOHNG AREAS. OUALITY } \\
\text { OF WATEA OENERALLY POOH BECAUSE OF HIOH } \\
\text { SULFATE CONCENTRATION. }\end{array}$ \\
\hline & TRIASSIC & UPPEA & $\begin{array}{l}\text { CHINLE } \\
\text { FORMATION }\end{array}$ & 1.100 & $\begin{array}{l}\text { SHALE, MED, AND CHANHEL DEPOSITS OF SMALY } \\
\text { SANDSTONE; CONTANS EEDS OF RED } \\
\text { SANDSTONE AT TOP AND DOTTOM. }\end{array}$ & 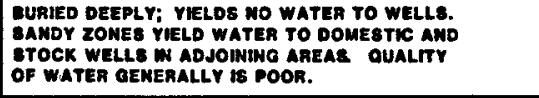 \\
\hline \multirow{6}{*}{ 号 } & \multirow[t]{4}{*}{ PERMIAN } & & $\begin{array}{l}\text { SAN ANDRES } \\
\text { LMESTONE }\end{array}$ & 47 TO 470 & $\begin{array}{l}\text { WTERBEDDED LMESTONE, GYPSUM, ANO } \\
\text { SANDSTONE. }\end{array}$ & $\begin{array}{l}\text { EUAIED DEEPLY; YIELDS WATER TO STOCK AND } \\
\text { DOMESTIC WELLLS IN ADJOHARG AREAS. }\end{array}$ \\
\hline & & & $\begin{array}{l}\text { GLORIETA } \\
\text { SAMDSTONE }\end{array}$ & 70 TO 220 & $\begin{array}{l}\text { EAMDSTONE, MINE-GRANED, EUFF TO WHITE, } \\
\text { CONTANS OYPSUM IN SOME AREAS. }\end{array}$ & Do. \\
\hline & & & $\begin{array}{l}\text { YESO } \\
\text { FORMATION }\end{array}$ & $\begin{array}{l}400 \text { TO } \\
1,100\end{array}$ & SANDSTONE AND SILTSTONE, TAM-BROWN TO REO & $\begin{array}{l}\text { EURIED DEEPLY: VIELDS LITTLE OA MO WATEA TO } \\
\text { WELLS. }\end{array}$ \\
\hline & & & AMO & $\begin{array}{l}610 \\
\text { oso }\end{array}$ & $\begin{array}{l}\text { BANDSTONE, FWE- TO COURSE-GRAMED, AND } \\
\text { EILT STONE; RED TO GRAY. }\end{array}$ & $\begin{array}{l}\text { DURIED DEEPLY; YIELDS EMALL OUAMTITIES OF WATEA } \\
\text { TO STOCK WELLE IN AD JOHNING AREAS. }\end{array}$ \\
\hline & \multirow[t]{2}{*}{ PEnws Ylvamian } & & $\begin{array}{l}\text { MADERA } \\
\text { LHESTONE } \\
\end{array}$ & $\begin{array}{l}480 \mathrm{TO} \\
2,000\end{array}$ & $\begin{array}{l}\text { LMESBTONE, GRAY TO RED; UPPER PART INCLUDES } \\
\text { MORE CLASTIC MATERIAL THAH LOWER PART. }\end{array}$ & $\begin{array}{l}\text { GURIED DEEPLY; AAKOSIC MEMBER YUELDS SMALL } \\
\text { OUANTTKES OF WATEA TO STOCK ANO DOMESTIC } \\
\text { WELLS W ADJOANINO AREAS. }\end{array}$ \\
\hline & & & $\begin{array}{l}\text { SANDIA } \\
\text { FORMATION }\end{array}$ & 0 TO 418 & $\begin{array}{l}\text { SAMDSTONE, SHALE, AND LIMESTONE, EROWN, } \\
\text { GAAY, RED, AND BLACK; UPPER PART GENERALLY } \\
\text { CLABTIC MATERIAL, LOWER PART OENERALLY } \\
\text { LIMESTONE. }\end{array}$ & $\begin{array}{l}\text { EUAIED DEEPLY; YIELOS BMALL OUANTTESS OF } \\
\text { WATER TO STOCK AND DOMESTIC WELLS WN } \\
\text { ADJOMINO AREAB. }\end{array}$ \\
\hline & PhEcambaian & 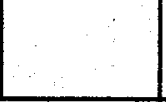 & & $18,000+$ & METAMORPHIC ANO KGNEOUS MOCKS. & $\begin{array}{l}\text { SUAFICIAL WEATHEAED AND FRACTURED ZONES } \\
\text { YIELD EMALL OUAHTTIES OF WATEA OF SPRWGS } \\
\text { AHD WELLS ALONG MOUNTAIN FRONT FOR STOCK } \\
\text { AND DOMESTIC SUPPLIES. }\end{array}$ \\
\hline
\end{tabular}

Figure 1. Generalized Section of Geologic Formations in the
Albuquerque Area, Bernallilo and Sandoval Counties,
New Mexico. 


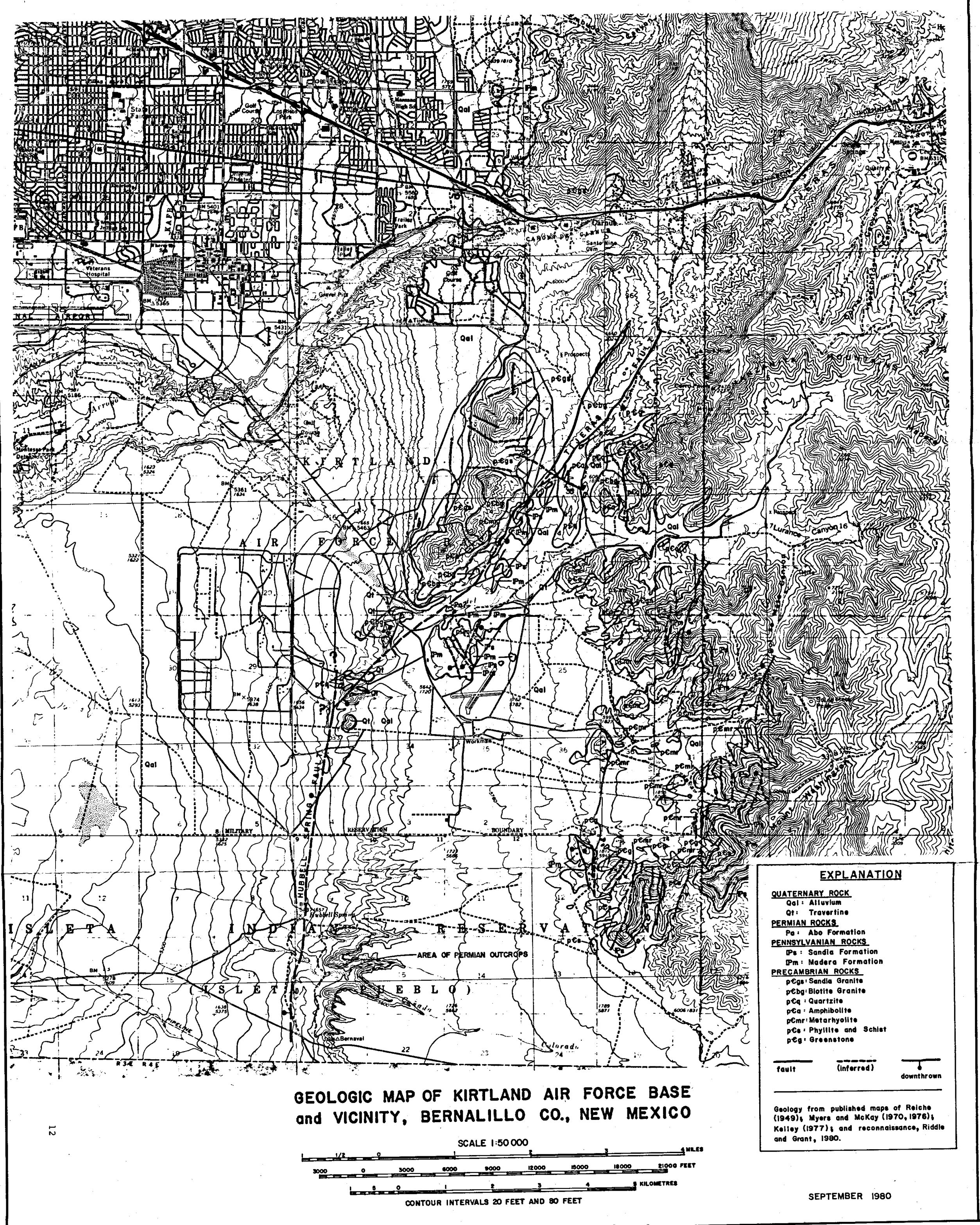


The granite exposure on the Manzano Base dips at least $45^{\circ}$ under the alluvium to the west (see discussion of geophysical surveys). South of the Tijeras and east of the Hubbell Springs fault the strata form a flat-lying bench covered with a thin veneer of alluvium. This flat, low-Iylng province is probably associated with the Manzanita uplift. West of the Hubbell springs fault the basement drops off drasticaliy to form the deep basin.

The Tijeras fault and the Hubbell Springs fault intersect near the center of the Base. The configuration of this intersection is unknown. The interpretation shown on Plate I is merely one of many, and agrees with Relche (1949). Other fauits cross the area, some of which are shown on Plate 1. Chuck Reynolds, of Reynolds and Assoclates, belleves 3 faults cross the south base boundary in section 4 (personal communfication). This idea is based on a seismic Iine that he conducted in 1976. Some Iimited evidence suggests a subsurface fault near the eastern edge of the golf course.

During our fleld investigation, we located extensive travertine deposits and plotted them on Plate 1 . Detalled field investigation should be conducted to define the Iimits of this unit. The travertine has a varlable character ranging from massive to conglomeritic. In places the conglomerate is composed of angular pink quartzite pebbles and cobbles. This particular conglomerate overiles a masslve travertine and was found in Coyote Arroyo. Another conglomeritic travertine is composed of 
Iimestone boulders and cobbles derived from the Madera foundation. This conglomerate was found in a road cut west of the Solar Power Tower. In addition to the outcrops in the arroyo, the travertine forms mounds of considerable topographic relief southwest of Manzano Base. The overall character of the travertine suggests deposition by springs. Also interesting to note is that the mounds occur along the Tijeras fault and at the supposed intersection of the Tijeras and Hubble Springs faults. The mound near coyote Springs, however, is an exception. It may be related to other faulting not indicated on plate 1 , but suggested by Myers and McKay (1970).

\section{Bydrology}

Unfortunately, the hydrology of the Albuquerque basin is practically unknown below 5000 feet. Most wells in the area are completed in the santa Fe formation above 1500 feet. A few oll and gas wells have been drilled through the Santa Fe and provide minimal yet valuable information. The following is a summary of data and speculation concerning the hydrology of the area.

The groundwater in the Rio Grande basin is under water table conditions. The water table slopes down from the Sandia and Manzano mountains in the east and from the Rio Puerco in the west. The depth to the water table increases away from the inner valley from 10 to 1000 feet toward the west mesa, and to 600 feet toward the east mesa. At the K1rtland base the water table occurs between 400-600 feet below the surface. Recharge to the groundwater system is accomplished by infiltration of precipitation 
and Irrigation water, seepage from streams, canals, and surface reservoirs, and by flow from adjacent areas. The water is discharged through springs, seeps, dralns, wells, and evapotranspiration (Bjorklund and Maxwell, 1961).

The principal aquifer in the basin is the valley fill. This f1II is composed of Quaternary alluvium and the Santa Fe formation. The alluvium is a unit of unconsolidated sand and gravel with local occurrences of silt, clay, and dune sand. This unit has a maximum thickness of 1000 feet and wiII yleld 500-1000 gallons per minute $(\mathrm{g} / \mathrm{m})$ of fresh water. Below the alluvium is the extensive santa Fe formation. This formation is thought to be $10,000+$ feet thick. Locally, it may be found 22,000 feet below the surface. The Santa Fe consists of unconsolldated to moderately consolidated sand, gravel, silt, clay, and volcanics. Wells completed in the Santa Fe can produce 500 to $2000 \mathrm{~g} / \mathrm{m}$ and will yleld fresh to slightly saline water. UnderIying the valley fill is a series of consolidated sedimentary strata ranging from Mississipplan to Tertiary age. The stra are interbedded 11 mestones, sandstones, and shales. A stratigraphic section is shown for reference in Figure 1. These units are not well known in the basin, but are generaliy not considered to be aquifers. Near thelr outcrops, however, the PermianMississippian rocks yield up to $500 \mathrm{~g} / \mathrm{m}$ of moderately saline to fresh water. At the base of the sedimentary units are Precambrian basement rocks. These rocks are lgneous and metamorphic and contain groundwater only in highly fractured and weathered zones. 
The water quality depends on the depth of the water-bearing zone (KeIIy, 1974).

T. E. Kelley (1974) divides the groundwater in the Rio Grande Basin into four units classified by salinity. In the AlbuquerqueBelen Basin he shows three units present: fresh, slightly saline, and moderately saline (Flg. 2). The saline and brine units have not been encountered in drillholes but would be expected if the sediments are present at depth. Kelly relates these salinity zones to aquifer temperature. Of interest are the moderately saline $(3-10 \mathrm{~g} / \mathrm{I})$ and saline units $(10-35 \mathrm{~g} / \mathrm{I})$. He predicts yields from these aquifers to be 100 to $500 \mathrm{~g} / \mathrm{m}$ and aquifer temperatures to be $80^{\circ}-100^{\circ} \mathrm{C}$ and $100^{\circ}-150^{\circ} \mathrm{C}$ respectively. In the Albuquerque area the $100^{\circ} \mathrm{C}$ to $150^{\circ} \mathrm{C}$ zone would be found between 9000 and 14,000 feet. These predicted temperature zones are confirmed by local oil and gas wells, as shown by Figure 3 .

\section{Heat Flow}

The Rio Grande rift is characterized by regional and local thermal anomalies. The regional anomaly may be the result of a thinning lithosphere with heat supplied by the upper mantie [Decker (1969) and Chapin (1971)]. Reiter et al (1975) suggest hydrothermal fluid migrations in deep fracture zones and possible shallow magma bodies as the cause. Cook et al (1978) also attribute high heat flow to the emplacement of shallow magma bodies. Other researchers favor emplacement of deep $(15-30 \mathrm{~km})$ magma bodies [Harder et al (1980), Reiter et al (1978)]. Local thermal anomalies could be the result of shallow, young $(<50,000$ yrs) 


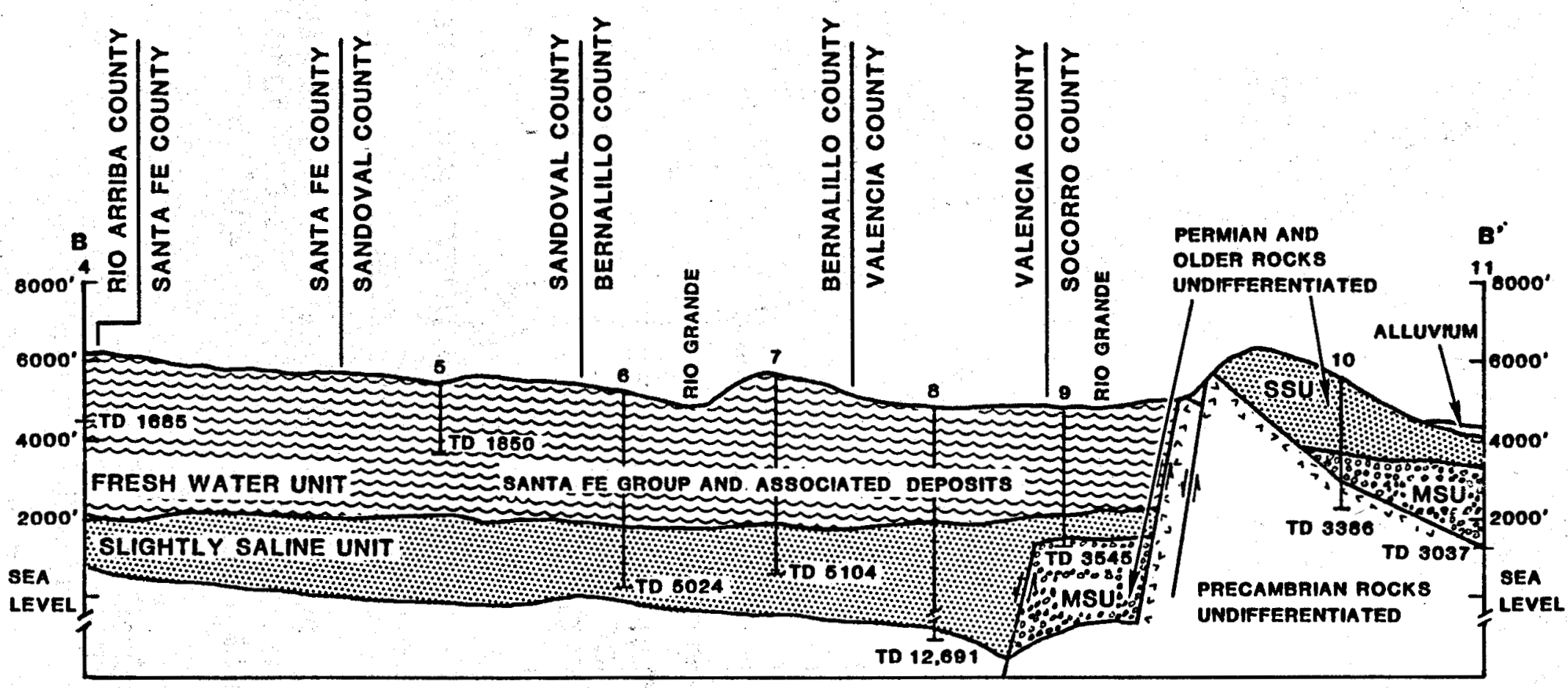

SCALE 1:250,000

KEY

T FRESH WATER UNT (1 om/D

FL.... SLIGHTLY SALNE UNIT (1-3 om/1)

:39:39 MODERATELY SALINE UNIT (3-10 om/1)

Figure 2. Groundwater Units in the Albuquerque-Belen Basin (Kelly, 1974). 
SHELL NO. 1

SANTA FE 11,045 TD

$236^{\circ} \mathrm{F} \mathrm{BHT}$

SHELL NO. 3
SANTA FE 10,276 TD

SHELL NO. 3
SANTA FE 10,276 TD
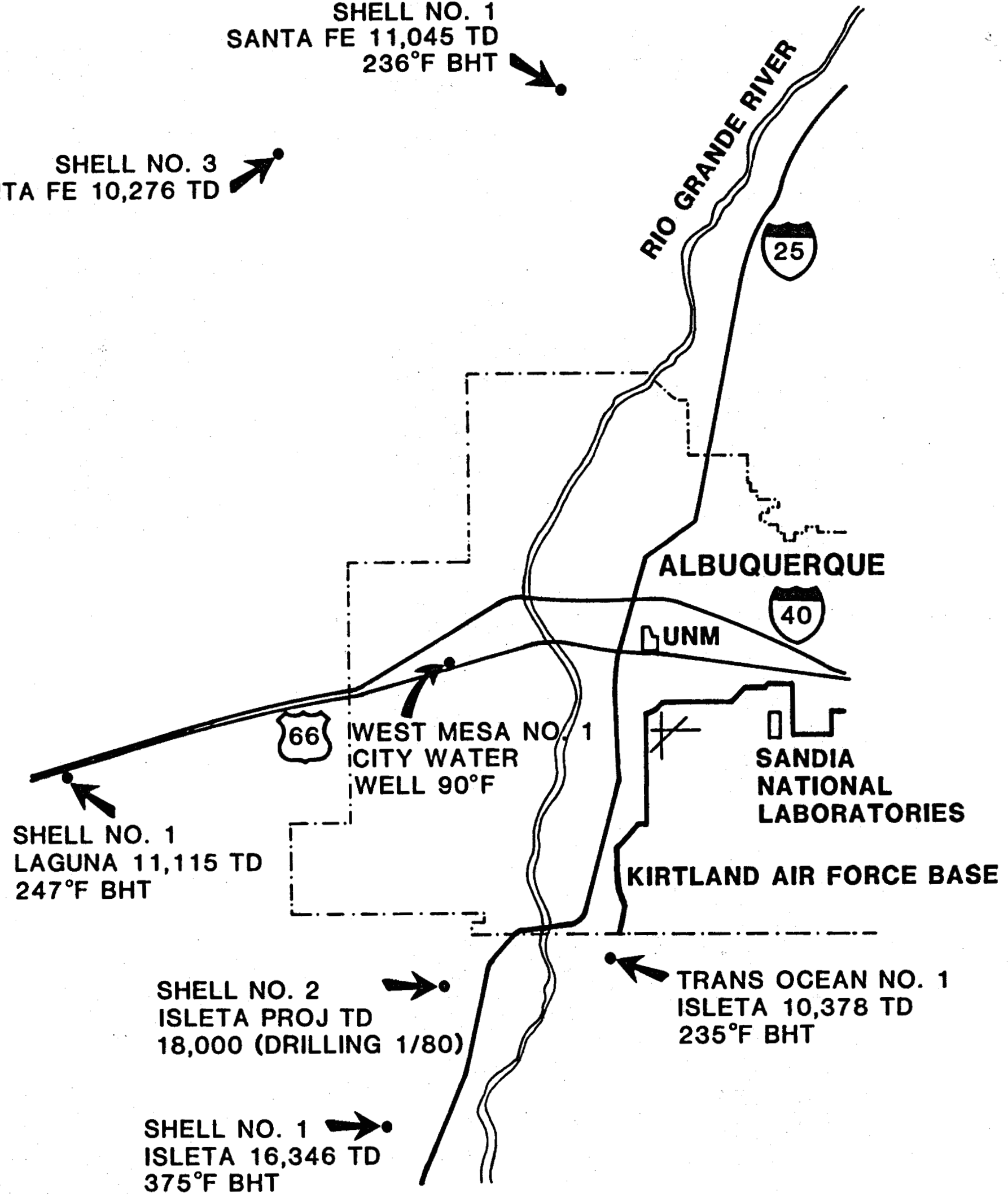

Figure 3. Location, Depth and Bottom Hole Temperature of Local Wells. 
intrusions, but forced groundwater convection is considered more reasonable [Harder et al, (1980), Parker and Jiracek, (1980)].

The north-south trend of the regional anomaly was mapped by Reiter et al $(1975,1979)$. This heat flow map is Included in Figure 4. Relter et al (1979) also calculated the heat flow for the Albuquerque-Belen Basin to be $2.35 \mathrm{HFU}$. However, the three heat flow holes tested near Albuquerque have measurements of $1.08,1.56$, and $1.43 \mathrm{HFU}$ (Reiter et al, 1978, 1979). In add1tion, the Kirtland base is located at the edge of the anomaly. where the heat flow ranges from less than 1.5 to 2.0 . These low heat flow values are not considered abnormal and are similar to values measured in the Great Plains province.

Parker and Jiracek (1980) have conducted a geothermal exploration program in Albuquerque. They used temperature gradients in oll and gas and water wells to evaluate the local geothermal potential. They discovered several anomalles: Llano de Atrisco west of Albuquerque; Volcanoe Cliffs, West Mesa; and several well flelds east of the Rlo Grande. They Interpret one of these anomalies as the result of deep water being forced over a burled magnetic feature. Except for these areas, the basin at Albuquerque has a normal geothermal gradient. Above $3 \mathrm{~km}$, a gradient of $33^{\circ} \mathrm{C} / \mathrm{km}$ should be expected, and below $3 \mathrm{~km}, 40^{\circ} \mathrm{C} / \mathrm{km}$ is expected.

Water wells at Kirtland do not produce abnormally warm water (J. Richardson, personal communication) and thus, no geothermal anomaly is expected. The alluvial section, however, may be deep 


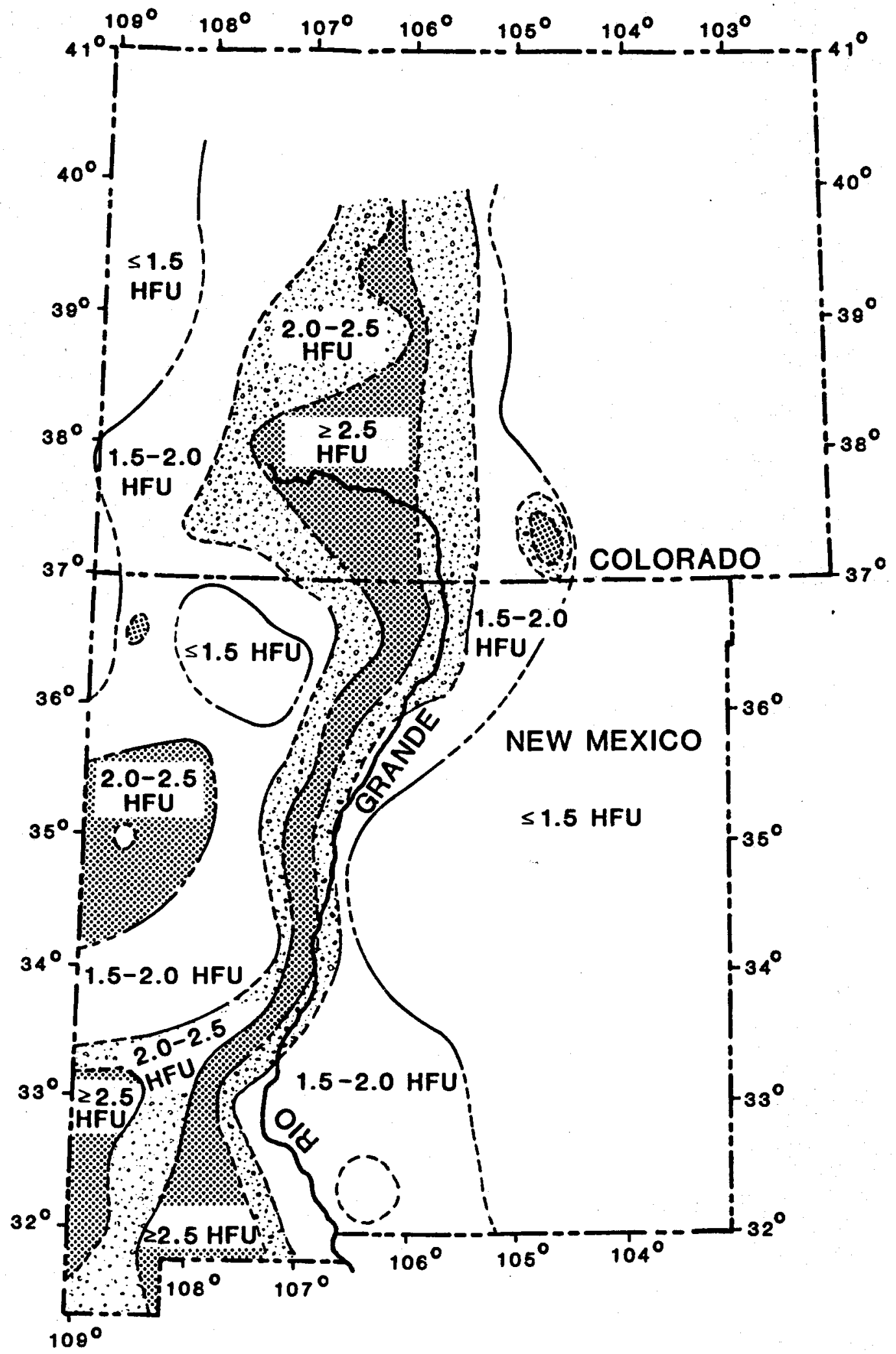

Figure 4. Heat flow map of New Mexico and Colorado (Reiter et al, 1979). 
enough to produce hot water heated by the normal geothermal gradient. Using the graph constructed by Parker and Jiracek (1980), shown in Figure $5,300^{\circ} \mathrm{F}$ water could be found between 12,000 and 14,000 feet. These data agree with predictions supplied by T. E. Kelly (1974), as discussed in the previous section.

\section{Geophysics}

Several geophysical studies have been conducted on the Rio Grande Rift (Cordel1, 1978). In general, these studies have been focused on regional trends. The results suggest that mantle materlal has penetrated the crust (Cordeli, 1976), Precambrian structures have influenced the cenozolc faulting (Cordeil, 1978) and the rift has relatively low seismicity compared to other continental rift zones (Cordell, 1978). The steep gravity gradients shown on Cordell's gravity map (Cordell et al, 1973) indicate the basin boundary faults. Cordeli's interpretation is 1llustrated in Figure 6. The Hubbell springs fault shown crosses the Rirtland Base.

The Albuquerque-Belen Basin has recelved considerable attention in recent years. Most studies, though, have been located near socorro and are programed toward characterizing a shallow $(19 \mathrm{~km})$ magma body thought to exist there [Re1Iinger et al (1980), Chapin et al (1978), Rinehart et al (1979), sanford et al (1977)) . other studies include selsmicity analysis, a detalled gravity profile, and a magnetic study. The selsmicity near Albuquerque can be related to known fault zones (Olsen et al (1979) and 


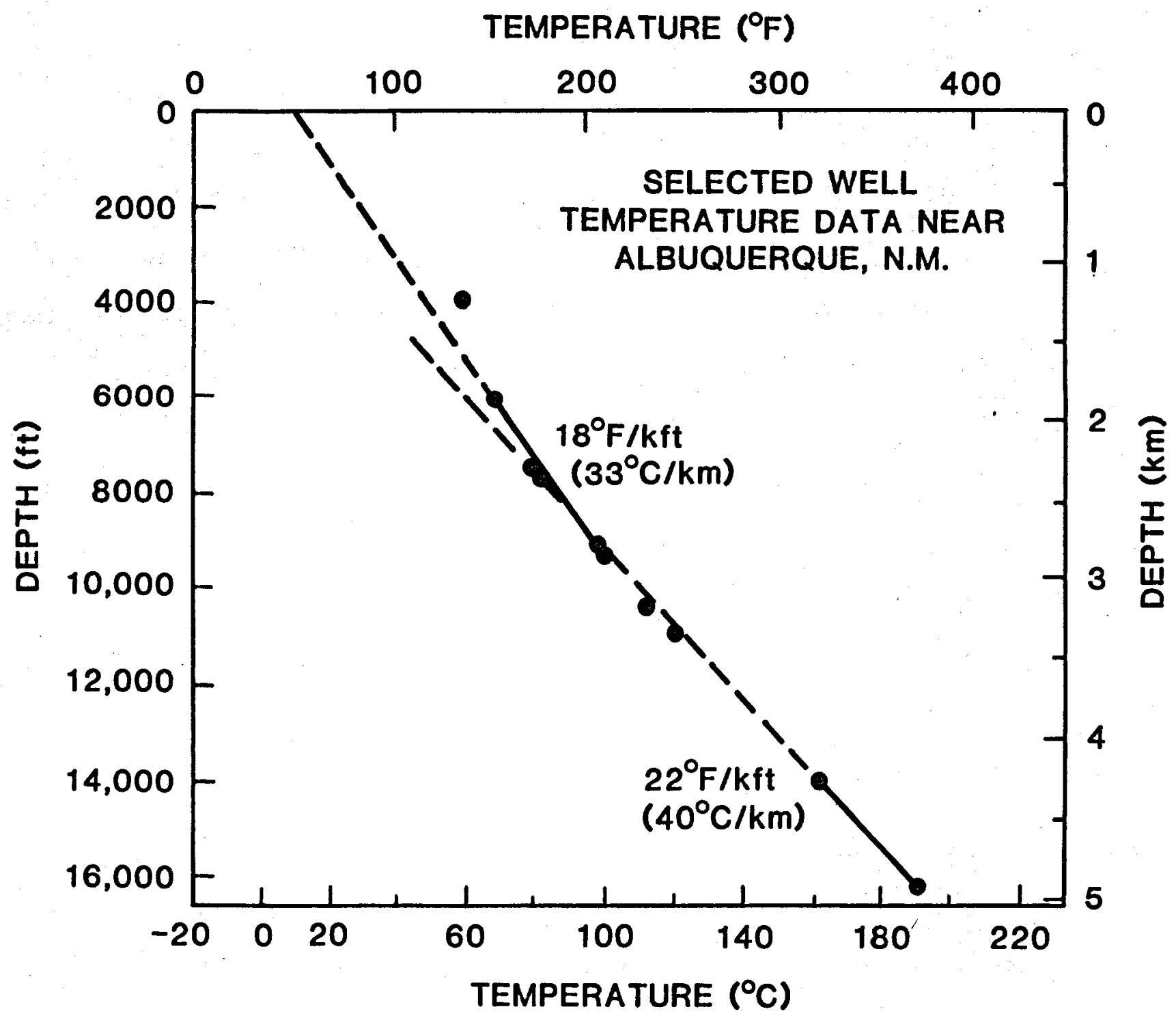

Figure 5. Temperature gradients at Albuquerque, New Mexico (Parker and Jiracek, 1980). 


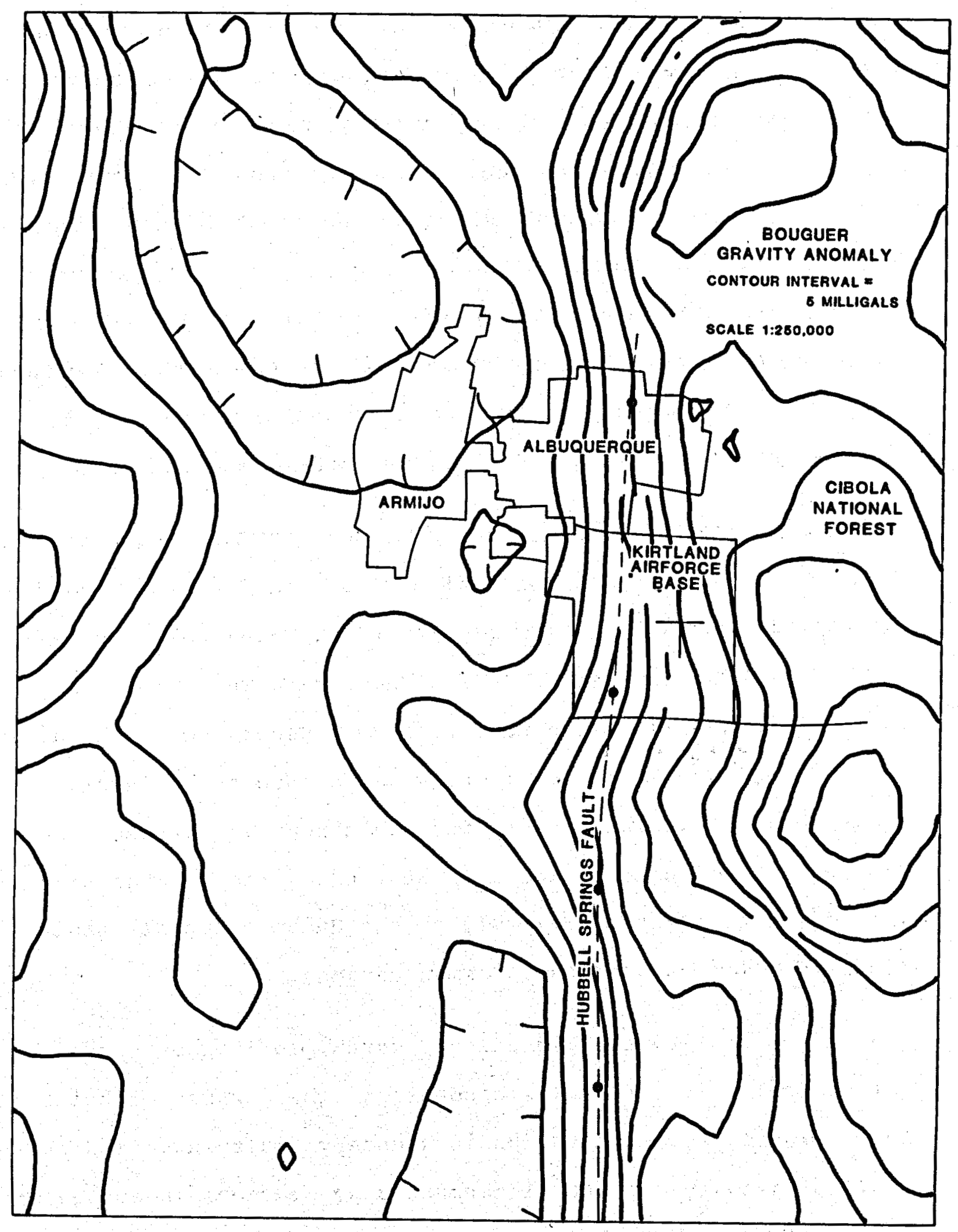

Figure 6. Bouguer Gravity Map of Albuquerque-Belen Basin Cordell (1973). 
Jaksha et al (1979)]. Cordell's detalled gravity profile is located along Tramway Road. His data suggest the presence of two burled faults. One of the faults probably has increasing rellef southward and the other has decreasing relief southward. At Tramway, the structural relief on one fault is approximately 1-2 kilometers (Cordell, 1978b). Cordell's gravity data were further utilized in a basin analysis by Birch (1980). One of Birch's maps shows the deepest part of the basin under kirtland (Fig. 7). The magmatic study is in progress; therefore, no results are avallable (M. Parker, personal communication).

Geophysical studies at the Rirtland Air Force Base are Ilmited. A local engineering firm, Roogle and Pools, conducted gravity readings and a Sandia group (Org. 2326) collected seismometer readings in Tech Area 1 . These data were used for experimental purposes and have no direct geological applications. In 1975 and 1976, a seismic survey was conducted by Charles Reynolds and Associates along the south boundary of the base. The results indicate at least three faults crossing the boundary in section 4. One of these may be the Hubbell Springs fault (Charles Reynolds, personal communication).

As part of this exploration program, an in-house audiomagneto-teliuric survey was conducted. The purpose of this survey was to look for the basin boundary fault suggested by the regional gravity map, and interpreted by previous investigators (Relche 1949, and Kelley and Northrup, 1975, Kelley, 1977). A description of the equipment and method used is described by 


\section{PROFILE * 1}

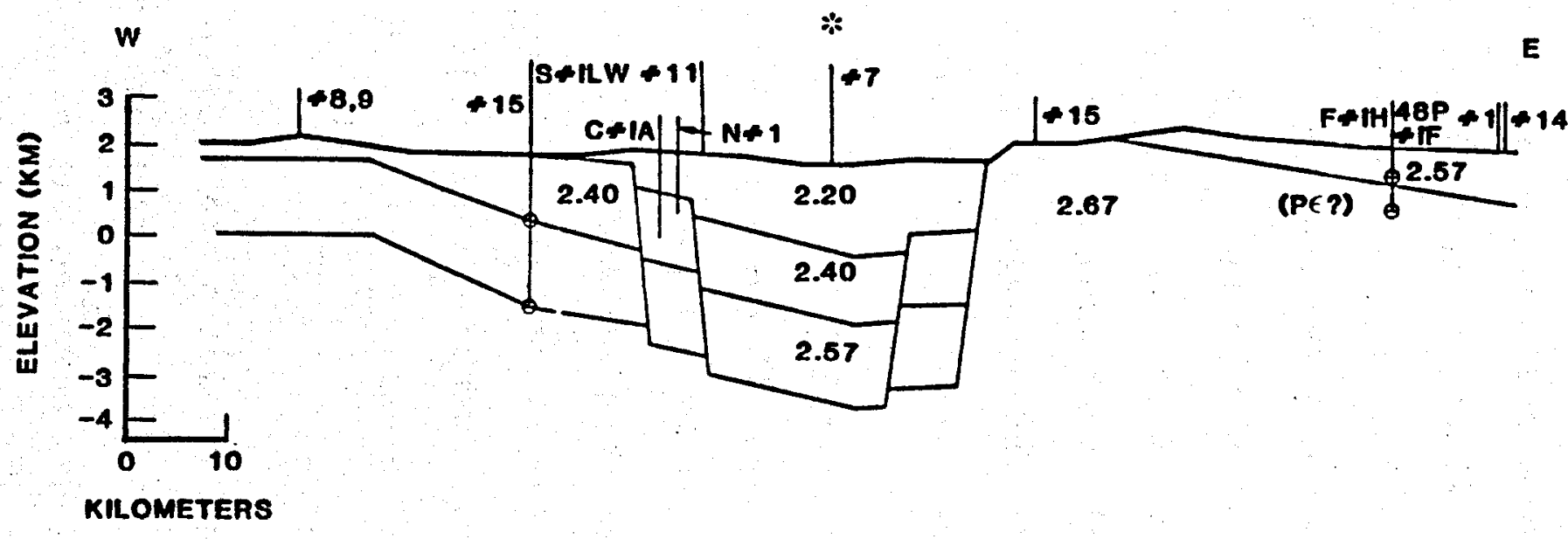

* indicates location of kiRtland base

Figure 7. Cross Section of Albuquerque-Belen Basin, Birch 
Bartel in the appendix. His interpretation is also included. The Precambrian outcrop on the Manzano base dips under the alluvium with at least a $45^{\circ}$ angle (L. Bartel, personal communication). Near the western limit of their survey, Bartel believes a fault is present. The alluvium at the site of the survey is a minimum of $1300 \mathrm{~m}$ thick (Bartel, see appendix). If this trend continued westward or the beds are down-faulted further west, a sedimentary section 15,000 feet thick or greater could be encountered under the Tech Area I. Thus, with the average geothermal gradient, and assuming a sufficient aquifer, water with temperatures near $150^{\circ} \mathrm{C}$ could be realized.

\section{Geochemistry and Geothermometry}

Geochemistry and geothermometry have been used to characterize and develop geothermal resources. The information acquired in these studies has been applied to exploration. The exploration sites have, however, been concentrated in areas of obvious geothermal activity. Swanberg (1975) illustrates that these techniques can also be used to detect a thermal component in non-thermal waters.

Several springs and wells are located on and around the Kirtland Air Force Base. None are known to have abnormal temperatures. Coyote springs, however, are highly mineralized and one emits a considerable amount of $\mathrm{CO}_{2}$. The chemical data presented here were acquired through three sources: the USGS WATSTORE file, the base engineering office, and from samples that we collected in the course of the study. The WATSTORE file contains information 
from both springs and wells. The locations of these springs and wells are shown in Figure 8 .

The sampling method we used was recommended by Fraser Goff of Los Alamos Sclentific Laboratory and is described in detall by Goff et al (1977) and Thompson. At each location, temperature, flow rate, $\mathrm{pH}$, and chlorlde were measured. Three sample bottles were also collected per site.

I $25 \mathrm{mI}$ bottle containing $90 \mathrm{ml}$ distilled water, to which $10 \mathrm{mI}$ filtered sample water was added $500 \mathrm{ml}$ bottle flitered sample water $500 \mathrm{mI}$ bottle filtered sample water acidified to a ph $\leq 2$

The samples were analyzed for major cations at the Los Alamos Laboratory. Atomic absorbtion spectros copy was used to determine concentrations of $\mathrm{SiO}_{2}, \mathrm{Fe}, \mathrm{Mn}, \mathrm{Ca}, \mathrm{Mg}, \mathrm{Na}, \mathrm{K}$, and sulfuric acid titration was used to determine $\mathrm{HCO}_{3}$ concentration. In addition, isotope samples were collected at Coyote springs, well 10, and Hubble spring. These samples were each contained in $125 \mathrm{ml}$ glass bottles. The 1sotope samples were analyzed for 180 and deuterium concentrations by $L$. Merlivat, Department de Recherche et Analyse, Saclay, France, by standard methods. The results of all analyses are shown in Table 1.

The chemlcal analyses performed allow the calculation of subsurface temperatures using equations developed by Fournier and Truesdell (1973), Fournier and Potter (1979), and Fournier and Rowe (1966). These equations are based on the assumptions 


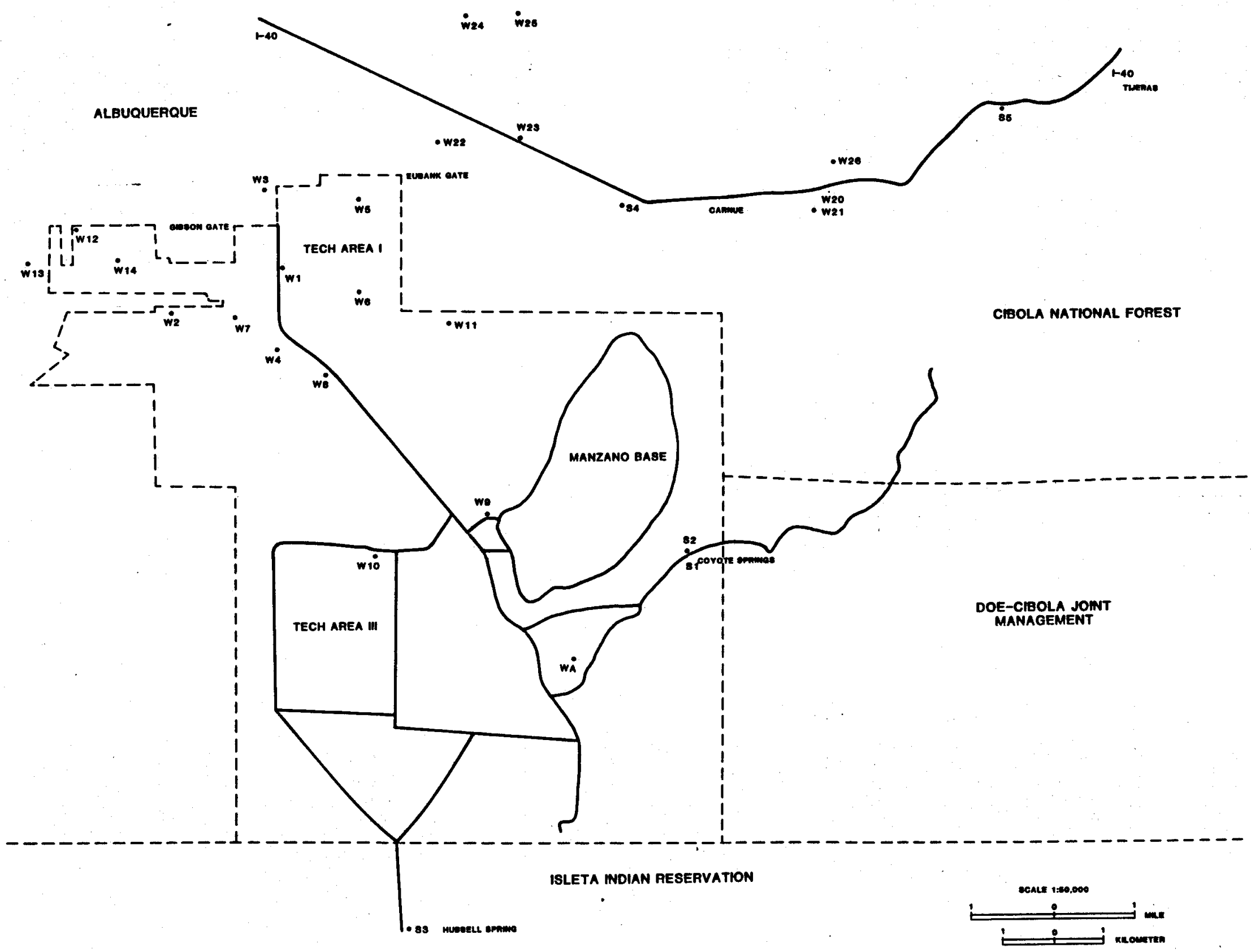

Figure 8. Location of Springs and Wells. 
Table 1. Chemical Analyses from the Kirtland Air Force Base Area

Well

or : (FE)

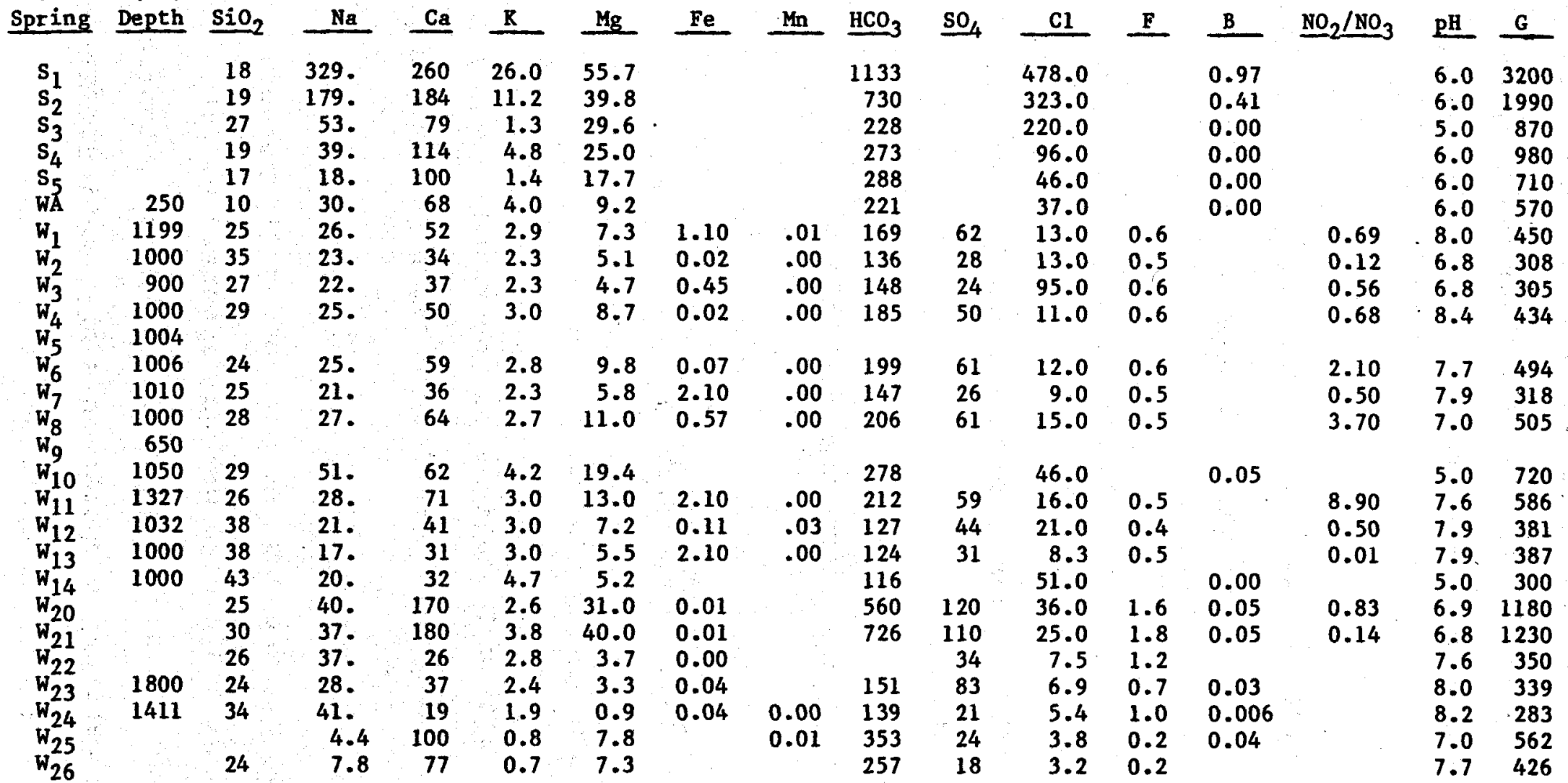

a) Samples $S_{1}-D_{5}, W A, W_{10}, W_{14}$ analyzed at Los Alamos Labs b) See Area Map for Spring and Well Locations Samples $W_{1}-W_{8}, W_{11}-W_{13}$ data from Base Engineering Samples $W_{20}-W_{26}$ from USGS WATSTORE file

Units in mg/1 except $p H, G$, and depth

$G=$ conductance in $\mu$ Mhos

depth $=$ feet 
that certain element concentrations in subsurface water are dependent on temperature and that their concentrations do not change during ascent to the surface. The geothermometer equations used are:

$$
\text { NaKCa } T\left({ }^{\circ} \mathrm{C}\right)=\frac{1647}{\log \left(\frac{\mathrm{Na}}{\mathrm{K}}\right)+\beta \log \left(\frac{\mathrm{Ca}}{\mathrm{Na}}\right)+2.24}-273.15
$$

where

$$
\begin{aligned}
& \text { Na, } K, \text { Ca are in molality } \\
& \text { and } \beta=4 / 3 \text { for low temperature and } 1 / 3 \text { for high temperature } \\
& \text { waters }
\end{aligned}
$$$$
\mathrm{SiO}_{2} \quad \mathrm{~T}\left({ }^{\circ} \mathrm{C}\right)=\frac{1315}{\left(5.205-\log \left(\mathrm{SiO}_{2}\right)\right)}-273.15
$$$$
\text { (quartz) }
$$$$
\mathrm{SiO}_{2} \mathrm{~T}\left({ }^{\circ} \mathrm{C}\right)=\frac{731}{\left(4.52-\log \left(\mathrm{SiO}_{2}\right)\right)}-273.15
$$$$
\text { (amorphous }
$$$$
\left.\mathrm{siO}_{2}\right)
$$

$$
\text { where } \mathrm{SiO}_{2} \text { is in mge }
$$

The results of these calculations can be found in Table 2. The temperatures indicate that normal subsurface conditions prevali.

As shown by the 1sotope plot in Figure 9, the waters follow the craig Meteoric Trend and thus are primarily meteoric. Coyote Spring has high $\mathrm{CI}$ and a high $\mathrm{N}-\mathrm{K}-\mathrm{Ca}$ temperature. This may be due to a component of connate water mixing with the meteoric water. The low $\mathrm{SiO}_{2}$ temperature supports this observation. All other geothermometer temperatures indicate normal conditions. 
Table 2. Subsurface Temperature Calculations from Geothermometers

Well or

Spring Temperature $\left({ }^{\circ} \mathrm{C}\right) \quad \mathrm{T}_{\mathrm{NaKCa}}\left({ }^{\circ} \mathrm{C}\right) \quad \mathrm{T}_{\mathrm{SiO}_{2}(Q)}\left({ }^{\circ} \mathrm{C}\right) \quad \mathrm{T}_{\mathrm{SiO}_{2}(\mathrm{AS})}\left({ }^{\circ} \mathrm{C}\right)$

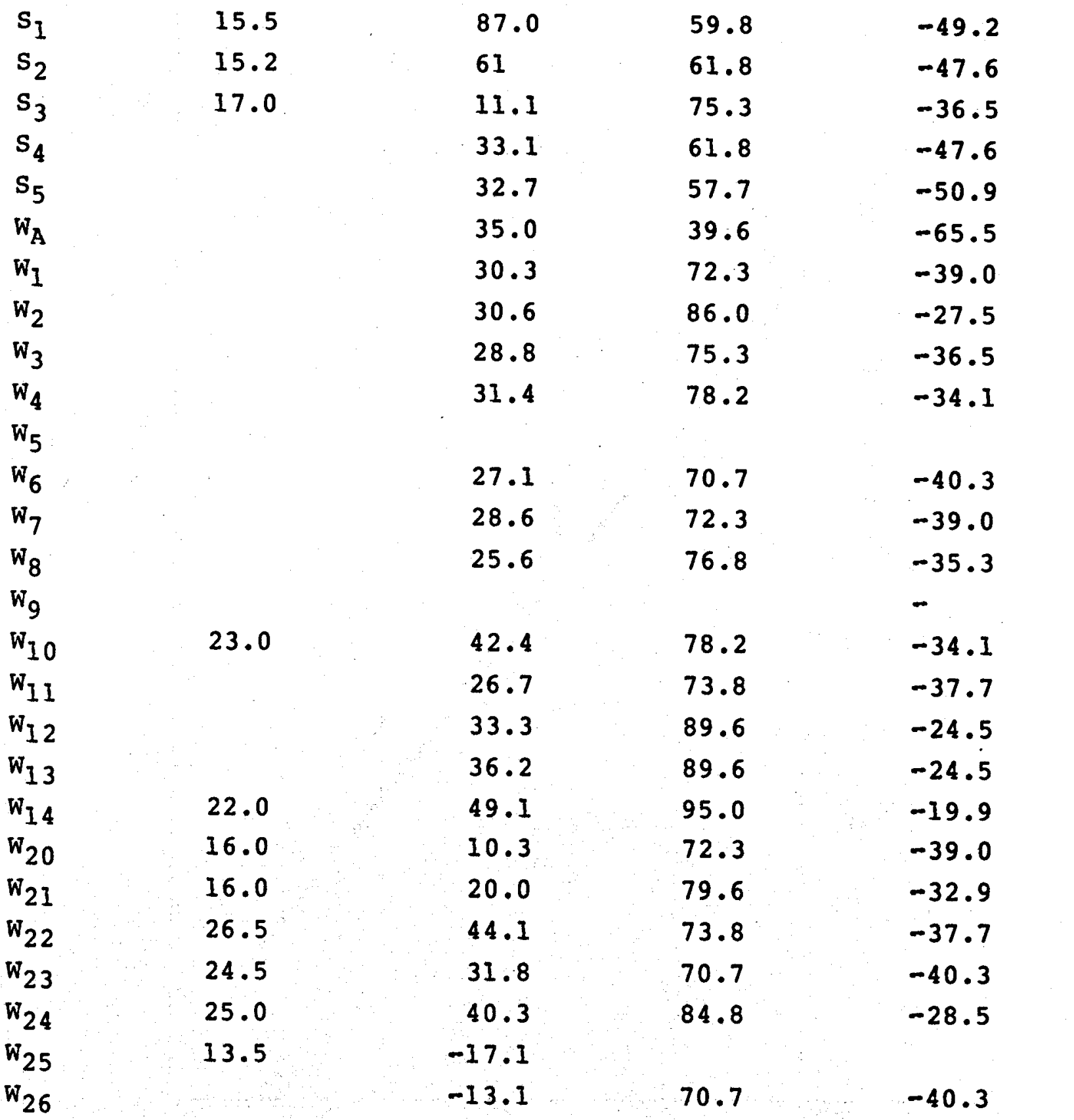

31 


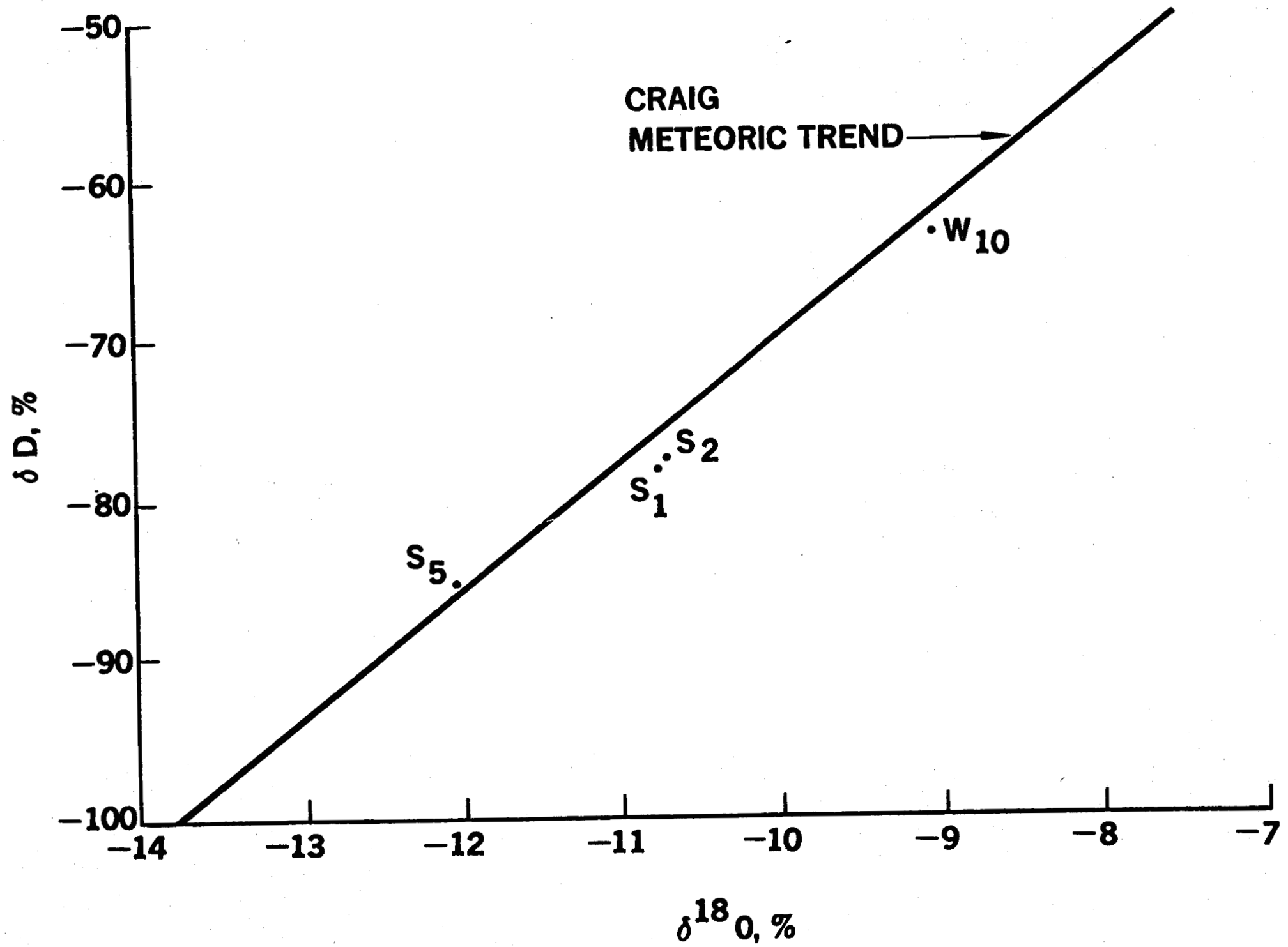

Figure 9. Ratio of Deuterium to ${ }^{18}$ o Concentration for Spring Water Samples. 


\section{Summary of Results}

This Investigation has revealed two potential models for tapping geothermal energy: the basin model and the fault model. The basin model will allow a deep well to be drilled near the existing steam circulation system. This close proximity to the system would eliminate losses due to fluid transport from a remote area. The fault model on the other hand could eliminate deep drilling. Due to remote fault location, the fault model would, however, require transport of the fluids $1-2$ miles to user location. These models are illustrated in Figure 10.

\section{Basin Model}

The deep Albuquerque-Belen Basin possibly extends east to the Kirtland Base area. Thus, a thick, water-saturated, alluvial section may underly the Kirtland Base. Below the alluvium, the Mesozolc and Paleozolc strata, if present, may contain Iimited amounts of water. These units would be useful if sediments are not present at depths required for sufficient temperature. A normal geothermal gradient of $33^{\circ} / \mathrm{km}$ down to $3 \mathrm{~km}$ and $40^{\circ} \mathrm{C}$ below $3 \mathrm{~km}$ is expected. To encounter $300^{\circ} \mathrm{F}$, the well would have to be drilled to 13,500 feet (Parker and Jiracek, 1980). The water at these depths is expected to be silghtly to moderately saline and would rise to the water table under hydrostatic head.

\section{Fault ModeI}

Several major faults cross the Base area and extensive travertine has been deposited at their intersection. The 
SE

KEY

$?$ FAULT

ALLUVIUM

SANTA FE FM

$\because$ MESOZOIC AND

PALEOZOIC STRATA

湆嗬 PRE-CAMBRIAN GRANITE

UPWARD MIGRATHN OF HEATED WATERS

SCALE : 1 IN. $=1$ MILE

DATUM IS MEAN SEA LEVEL

CROSS SECTION OF BASIN MODEL

CROSS SECTION OF

FAULT MODEL

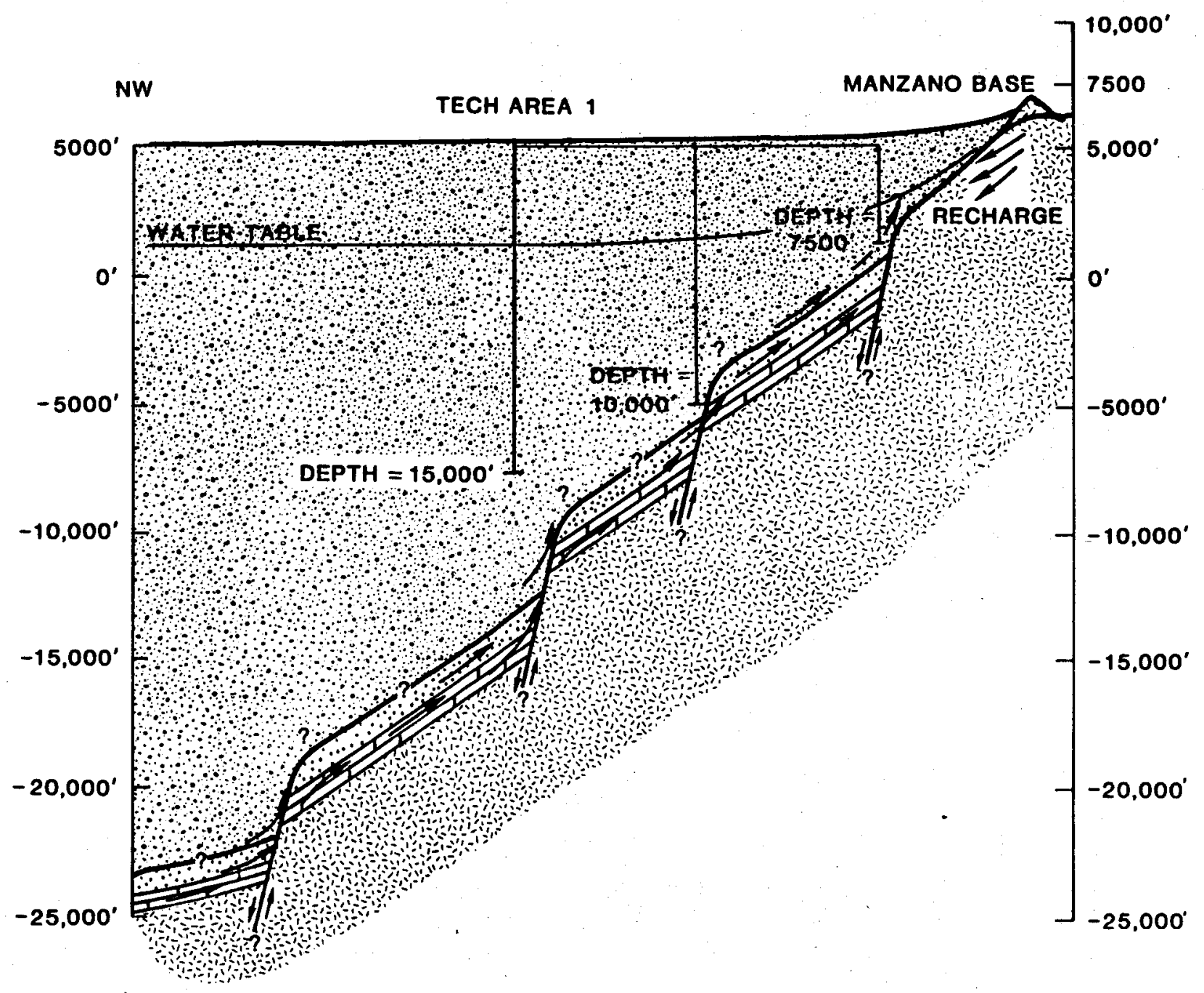

Figure 10. Cross Section Showing Basin and Fault Models. 
travertine does not require hot waters, but is common to hot spring activity. The travertine does suggest that large quantities of water have migrated in the faults. The geochemical data do not support thermal fluids. The geochemical data may, however, be masked by the large amounts of cold meteorlc water injected in the nearby mountains. If water in the basin is heated, it would become buoyant and migrate along faults to the surface. Depending on the depth of origin of the water, its temperature and salinity would have a wide range of possibilities.

The above models each have a fundamental question to be answered. Are the sediments thick enough and water-saturated under the Kirtiand Base? Is there water of sufficient quantity and temperature in the fault zones? We have initiated a program to answer these questions. We have communicated with Larry Jaksha of the U.S. Geological Survey Selsmological Lab and several workers at the civil Englneering Research Facility (CERF). We hope to use the upcoming CERF explosive tests and possibly monitor explosives at the Jackpile Mine near Grants, New Mexico in a seismological exploration program. sufficient equipment may be acquired in-house or elsewhere to monitor these explosives. The results of these studies could be used to estimate basin thickness and to pinpoint subsurface faults.

In addition to the above program, other studies should be conducted to complete the preliminary survey. Depending on the amount of equipment available, and the quality of the results, 
the project may move on to temperature gradient holes. The value of shallow temperature-gradient holes should be investigated. Several factors, including current knowledge of gradients, effect of the water table and cold water recharge, and depth necessary for rellable results, must be considered before the expense is taken to acquire these data. Studies also need to be conducted to further define the Iimits of the travertine and the nature of exposed fault zones. Extensive seismological studies may be required, such as a series of of VIBROSEIS Iines, to acquire definitive subsurface data. 
APPENDIX A

Use of CSAMT Technique to Map a Fault on RAFB 
, 


\section{APPENDIX A}

Use of CSAMT Technique to Map a Fault on KAFB

L. C. Bartel and C. W. Ray, 4737

R. D. Jacobson and P. M. Drozda, 4734

The controlled source audio-magnetotelluric (CSAMT) electromagnetic (EM) geophysical prospecting technique was used to locate a major fault on Kirtland Air Force Base. The CSAMT technique utilizes signals produced by a transmitter operating at selected frequencies. The ordinary AMT technique utilizes random occurring signals from natural sources. Under certain circumstances the plane wave interpretations of data for the ordinary AMT can be applied to the CSAMT.

The CSAMT technique is an EM induction technique where the primary EM field is produced by a long dipole (bipole) laid out on the surface of the earth and grounded at both ends with a transmitter located at the center of the dipole. The receiving antenna used for these measurements consists of a relatively short dipole in contact with the earth at both ends to measure the electric fleld and a ferrite wound coil to measure the magnetic fleld. Figure $A-1$ lliustrates the technique where the transmitting and recelving antennas are shown. The electric field $\left(E_{X}\right)$ is measured parallel to the transmitting antenna, and the magnetic field $\left(\mathrm{H}_{\mathrm{Y}}\right)$ is measured perpendicular to the transmitting antenna. The z-direction is into the earth. Data were recorded using a microprocessor controlled data acquisition system. 


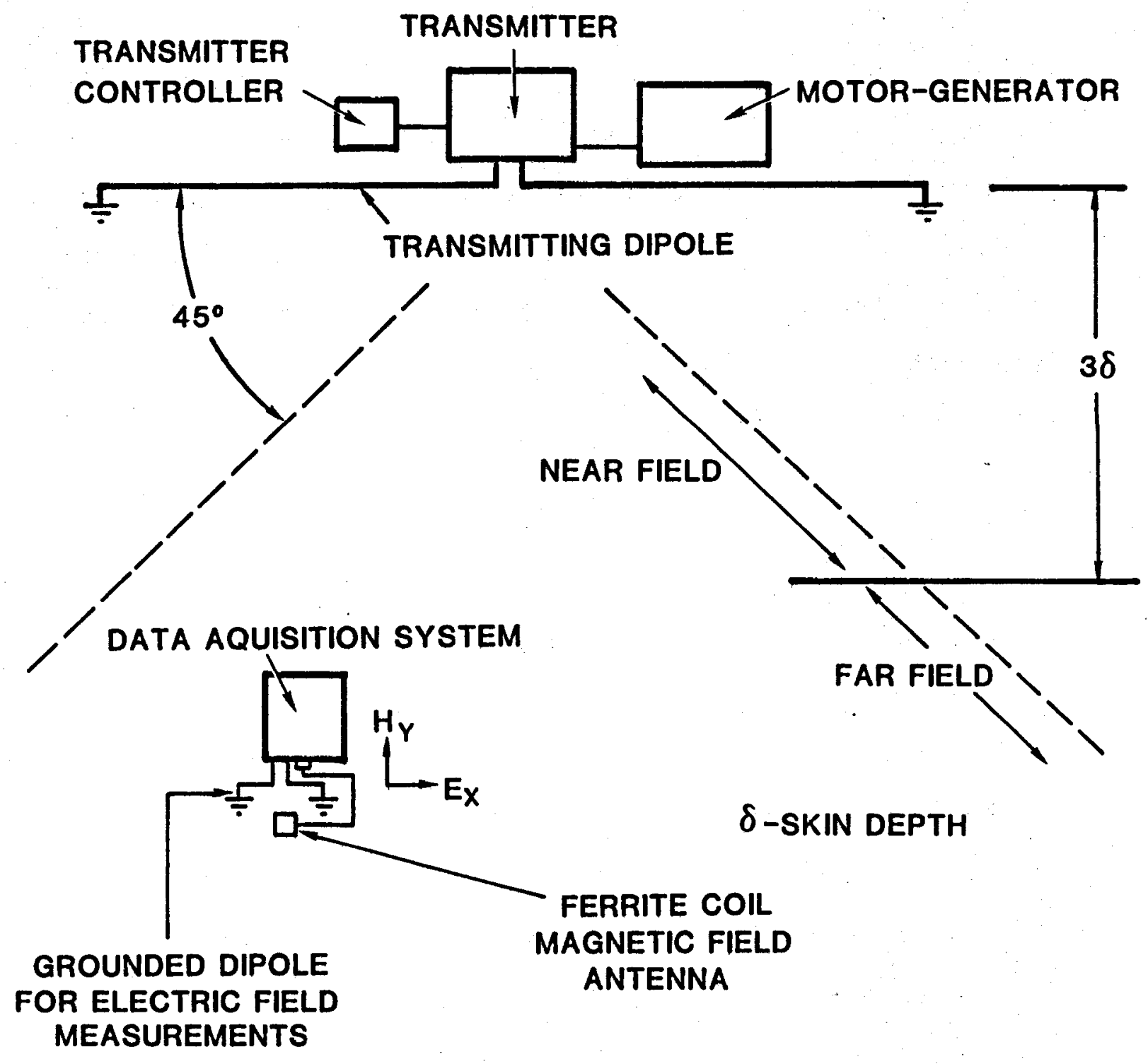

Figure A-1. CSAMT Geometry 
The wave impedance is related to $\mathrm{E}_{x} / \mathrm{H}_{\mathrm{y}}$ and the apparent resistivity $\rho_{\mathrm{a}}$ in ohm-metres is given by

$$
\rho_{a}=\frac{1.26 \times 10^{5}}{f}\left(\frac{E_{x}}{H_{y}}\right)^{2}
$$

where $\mathrm{E}_{X}$ is measured in volts/metre, $\mathrm{H}_{Y}$ is measured in volts/amp, and $f$ is the frequency. The skin depth $\delta$ is given by

$$
\delta=503 \sqrt{\rho_{a} / E}
$$

When measurements of the EM flelds are made at distances greater than $3 \delta$ (far fleld region) from the transmitting antenna, the apparent resistivity calculated using Eq. (1) corresponds to the "true" apparent resistivities. In the far field region plan wave solutions are appropriate. Measurements made at distances less than $3 \delta$ (near field region) yield an apparent resistivity wh1ch will be higher than the "true" apparent resistivity. Even though the near field resistivity values do not represent the "true" apparent zesistivities, the near fleld measurements can be used to delineate subsurface variations if there are sufficient resistivity contrasts. Note that in order for the far fleld measurements to represent the "true" values of apparent resistivity, the measurements must be taken in the region within $45^{\circ}$ about the perpendicular to the dipole, through the transmitter, as shown in Figure $A-1$.

The location of the survey Iines along with the transmitter locations are shown in Figure A-2. The survey was done in parts of sections 9 and 10 . The bearing of the transmitter line and 


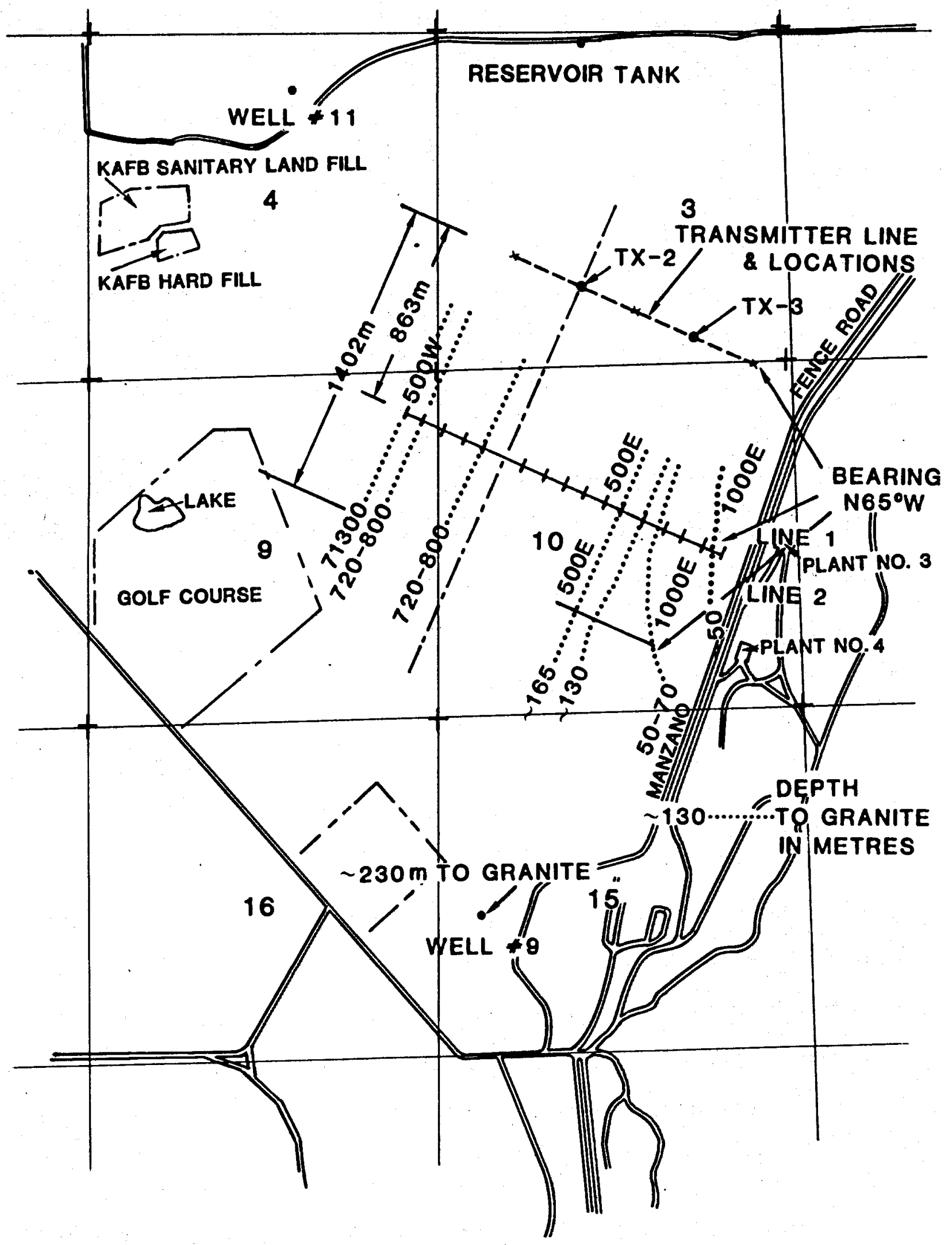

Figure A-2. Locations of Transmitter and Survey Lines. Depth to granite is indicated. 
the survey ines is $\mathrm{N} 65^{\circ} \mathrm{W}$. The length of the transmitting dipole was $610 \mathrm{~m}(2000 \mathrm{ft})$ and the length of the receiving dipole was $100 \mathrm{~m}(328 \mathrm{ft})$. The station numbers refer to east and west of the centerline of transmitter $-2(T x-2) ;$ e.g. $800 \mathrm{E}$ means $800 \mathrm{~m}$ E of centerline. To accommodate stations $800 \mathrm{E}$ through $1100 \mathrm{E}$, the transmitter was moved to the $\mathrm{Tx}-3$ location with again a $610 \mathrm{~m}$ dipole antenna. The two survey lines were located $863 \mathrm{~m}(2831 \mathrm{ft})$ and $1402 \mathrm{~m}(4600 \mathrm{ft})$, respectively, from the transmitter antenna, as shown in Flgure A-2.

Contours of equal apparent resistivity are displayed in Figures $A-3$ and $A-4$ for the two survey lines. The horizontal axis is station location and the vertical axis is log frequency. Because of skin depth affects, the vertical axis has the appearance of depth. The dashed lines separate the far (above the ine) from the near (below the line) field data. The sediments have a much lower resistivity than the granite basement rock. The resistivity contours point up sharply the sediments-granite interface. The resistivity values displayed in the lower left hand corner are extremely large because these are near fleld results and do not accurately portray the "true" apparent resistivity values.

Using a three-layered earth plane-wave Impedance calculation, the depths to the granite were estimated for various station locations. The three layers consisted of a resistive surface layer as evidenced by the higher resistivities at the higher frequencies, a fairly conductive intermediate layer as evidenced 


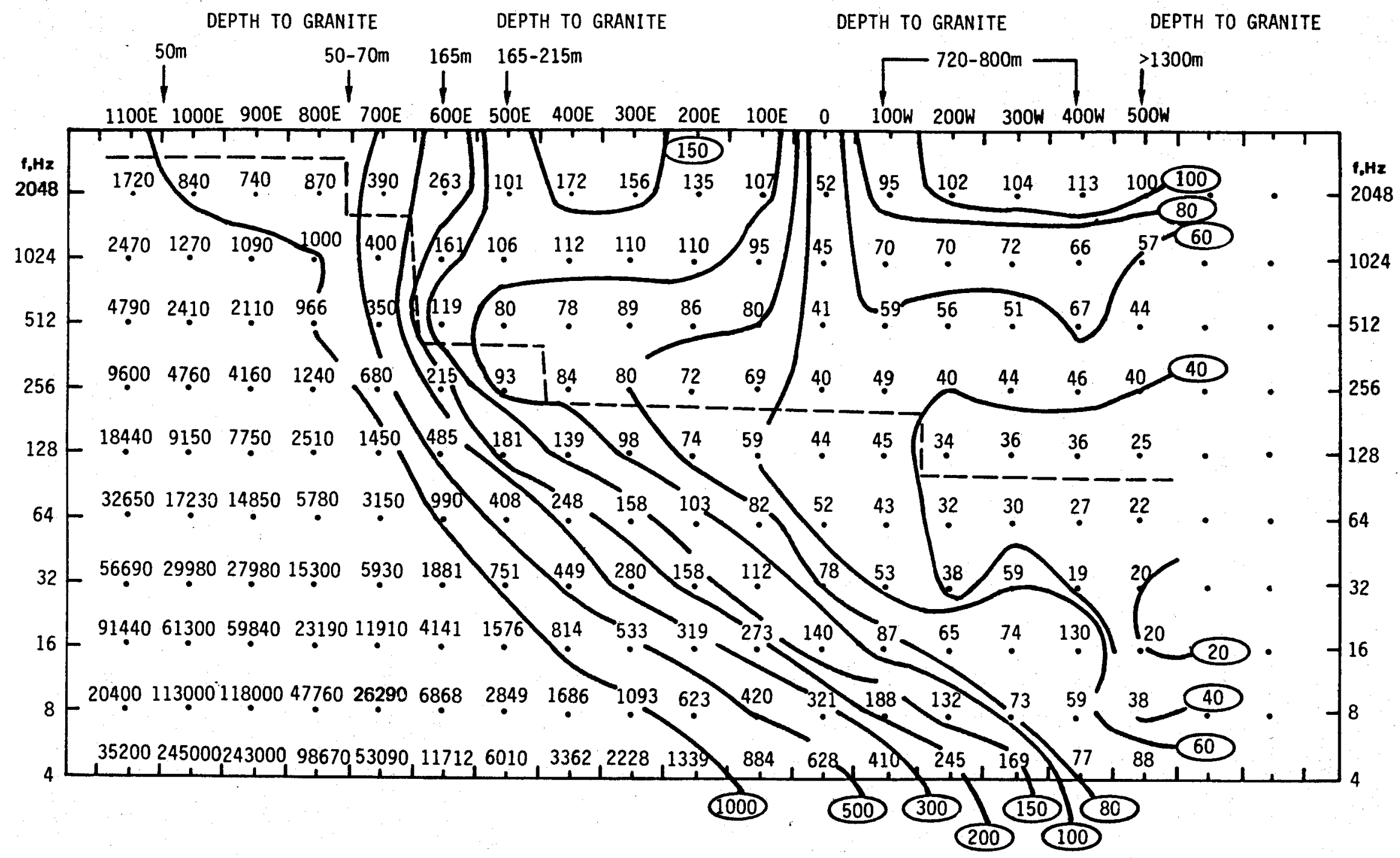

Figure A-3. Apparent Resistivity Contours for survey Line in Fig. A-2. 


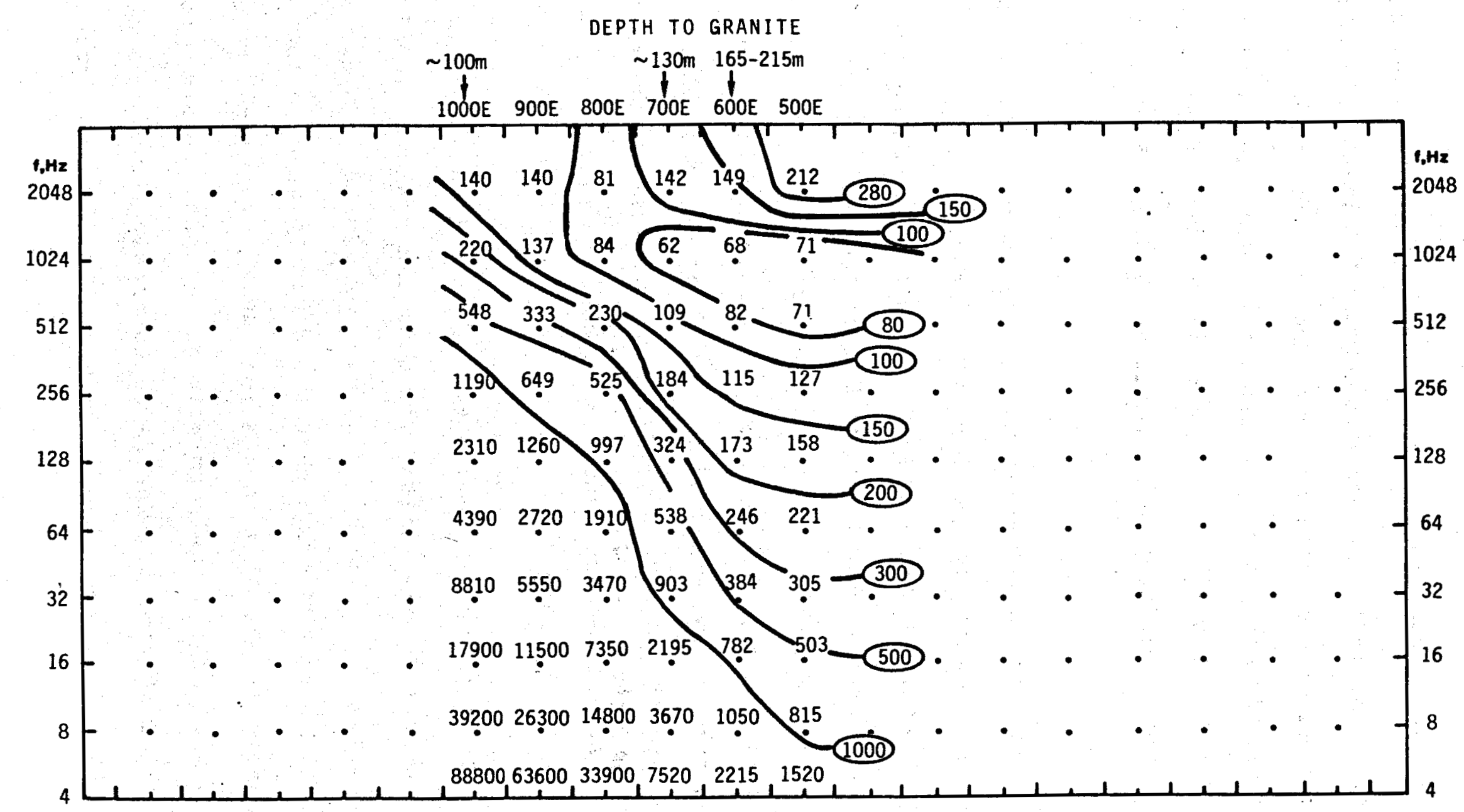

Figure A-4. Apparent Resistivity Contours for Survey Line in Fig. A-2. 
by the lower resistivities at the intermediate frequencies, and a high resistive granite basement. The depth estimates at a given station were made by comparing the frequency at which the far field resistivity increases for decreasing frequency (e.g., $256 \mathrm{~Hz}$ at station $400 \mathrm{E}$ line 1) to the calculated resistivities. The depth to granite estimate is $165-215 \mathrm{~m}$ at station $400 \mathrm{E}$ on line 1.

At some stations the far field data do not exhibit this increase in resistivity for decreasing frequency. At these stations, depth estimates are only inferred by noting the frequency for which there is a significant increase in the near field resistivity data for decreasing frequency. It is noteworthy that the near fleld apparent resistivity is always larger than the "true" apparent resistivity. For example, at station $400 \mathrm{~W}$ on line 1 there is a significant increase in the near field resistivity at frequency $16 \mathrm{~Hz}$ corresponding to a depth to granite of $\sim 720-800 \mathrm{~m}$.

The depth to granite estimates are shown in Figures $\mathrm{A}-3$ and A-4 for the two survey lines. The data taken along line 1 suggest that there may be a "bench" at a depth of 720-800 m between stations $100 \mathrm{~W}$ to $400 \mathrm{~W}$ and that the depth to granite increases significantly to $\sim 1300 \mathrm{~m}$ at station $500 \mathrm{w}$. The depth to granite decreases more or less uniformly in going from station 0 to station $700 \mathrm{E}$ of line 1. The depth to granite between stations $700 \mathrm{E}$ to $1100 \mathrm{E}$ is a depth of $\sim 50-70 \mathrm{~m}$. The depth to granite 
shown in Figure A-4 for II ne 2 corresponds to those for 1 line 1 . The depths to granite are also indicated in Figure A-2.

The depths to granite estimated from the CSAMT data agree favorably with the depth measured in Well \$9, Figure A-2. At the Well \#9 location the depth is $\sim 230 \mathrm{~m}$. East of the survey line the granite outcrops. Analysis of the data Indicates that the CSAMT technique can be used to map this fault.

47 


\section{REFERENCES}

Birch, Francis S. "Geophysical Evaluation of Basin Hydrologic Characteristics in the Central Rio Grande," Part I: Gravity Models of the Albuquerque-Belen Basin, Part II: New Gravity Maps of the Albuquerque-Belen Basin, New Mexico, in publication.

Bjorklund, L. J. and B. W. Maxwell. "Avallability of Groundwater in the Albuquerque Area, Bernalillo and Sandoval Co.. NM," New Mexico State Engineer, Tech. Rept. 21,117 p, 1961.

Chapin, C. E. "The Rio Grande Rift, 1, Modifications and Additions, Guidebook of the San Luis Basin," ed. by H. L. James, 191-201 New Mexico Geological Society, 1971.

Chapin, C. E., R. M. Chamberlin, G. R. Osburn, D. W. White, and A. R. Sanford. "Exploration Framework of the Socorro Geothermal Area, NM. Field Guide to selected Cauldrons and Mining Districts of the Datil-Mogollon Volcanic Field," New Mex. Special Publ. No. 7 ed. by Chapin, C. E. and W. E. Elston, 115-129, New Mexico Geological Society, 1978.

Cook, F. A., Decker, E. R., and Smithson, S. B. "Preliminary Transient Heat Flow Model of the Rio Grande Rift in Southern New Mexico," Earth and Planetary Science letters, 40 , pp $316-326,1978$.

Cordel1, L. "Aeromagnetic and Gravity studies of the Rio Grande Graben in New Mexico Between Belen and Pilar," Tectonics and Mineral Resources of Southwestern North America, Spec. Publ. No. 6 ed. by L. A. Woodward and S. A. Northrup, 62-70, New Mexico Geological Society, 1976.

Cordell, L. "Regional Geophysical Setting of the Rio Grande Rift," Geol. Soc. Amer. Bull. 89 1073-1090, 1978a.

Cordell, Lindrith. "Gravity Profile Along Tramway Road," in Guldebook to Rio Grande Rift in New Mexico and Colorado, compiled by J. W. Hawley, New Mexico Bureau of Mines and Mineral Resources Circular $163 \mathrm{pp} 156-158,1978 \mathrm{~b}$.

Cordell, L. E., Jowting H. R. and Case, J. E. Gravity Map of Albuquerque-Grants area, U.S. Geol. Survey open file map, Scale 1:250,000, 1978 .

Decker, E. R. "Heat Flow in Colorado and New Mexico," Journal of Geophysical Research, Vol. 74, No. 2, Jan. 15, 1969.

Goff, Fraser E., Donnelly, Julle M., Thompson, J. M., Hearn, B. Carter Jr. "Geothermal Prospecting in The Geysers-Clear Lake area, Northern Californla," Geology V.5 pp 509-515, August 1977 . 
Fournier, R. O. and Potter, R. W. II. "Magneslum Correction to the Na-K-Ca Chemical Geothermometer," Geochimica et Cosmochimica Acta Vol. 43, pp. 1543 to $1550,1979$.

Fournier, R. O. and J. J. Rower. "Estlmation of Underground Temperatures from the silica Content of Water from Hot springs and Wet-steam Wells" Am, Journal Sc1., 264, 685-697, 1966.

Fournier, R. O. and Truesdell, A. H. "An empirical Na-K-Ca Geothermometer for Natural Waters," Geochimica et Cosmochimica Acta, Vol. 37, pp. 1255 to 1275. Pergamon Press. Printed in Northern Ireland, 1973.

Geothermal Report, Vol. IX No. 11, Maria Carmen Smith (Publishereditor), June 1,1980 .

Harder, Vickl, Morgan, Paul, and Swanberg, Chandler A. "Geothermal Resources in the Rio Grande Rift: Origins and Potential," Transactions of the Geothermal Res. Co., In press.

Jaksha, Lawrence H. , Locke, J and Gebhart, H. J ., Microearthquakes near the Albuquerque Volcanoes, New Mexico.

Kelley, V. C. "Geology of the Albuquerque Basin, New Mexico Bureau of Mines and Mineral Resources," Mem. 33, 1977.

Kelley, V. C. and Northrup, S. A. "Geology of Sandia Mountains and Vicinity, New Mexico," New Mexico Bureau of Mines and Mineral Resources Mem. 29, 1975.

Kelly, T. E. "Reconnalssance Investigation of Ground water in the Rlo Grande Drainage Basin-With Special Emphasis on Saline Ground Water Resources," Hydrologlc Investigations Atlas, HA-5I0 published by the U.S. Geological Survey, 1974.

Myers, Donald A. and E. J. McKay, Geologic Map of Mount Washington Quadrangle, Bernalillo and Valencia Counties, New Mexico, U.S. Geological Survey Map GQ-886, 1970.

Myers, Donald A. and E. J. McKay, Geologlc Map of the North End of the Manzano Mountains, Tijeras and Sedilio Quadrangles, Bernal1110 County, New Mexico, U.S. Geologic Survey, Map 1-968, 1976.

Olsen, R. H., Keller, G. R., and stewart, J. N., Crustal structure along the Rio Grande Rift from Seismic Reflection Profiles, in "Rio Grande Rift: Tectonics and Magnetism" Robert E. Reicker, ed. American Geophysical Union, 1979.

Parker, M. D. and Jiracek, C. R. "Progress Toward Evaluating the Geothermal Resource in the Albuquerque, New Mexlco area," submitted to Geothermal Resources Council for presentation at 1980 Annual Meeting and publication in Transactions, Vol. 4. 
Relche, Parry. "Geology of the Manzanita and North Manzano Mtns. New Mexico," Geol. Soc. America Bull. V 60 p 1183-1212, 1949.

Rellinger, Robert, Oliver, Jack, Brown, Larry, Sanford, Allan, Balazs, Emery. "New Measurement of Crustal Doming Over the Socorro Magma Body, N. Mexico," Geology V 8, p 291-295, 1980.

Rinehart, E. J., Sanford, A. R., and Ward, R. M. Geographic Extent and Shape of an Extensive Magma Body at Midcrustal Depths in the Rlo Grande Rift near Socorro, New Mexico, in "Rio Grande Rift: Tectonics and Magnetism," Riecker, R. E. ed, Washington, DC American Geophysical Union p 237-251.

Reiter, M., C. Edwards, H. Hartman and C. Weidman. "Terrestrial Heat Flow Along the Rlo Grande RIft, New Mexico and Southern Colorado," Geol. Soc. Am. Bull. $86811-818,1975$.

Reiter, M., Shearer, C., and C. L. Edwards. "Geothermal Anomalies Along the Rio Grande Rift in New Mexico," Geology V 6 p 85-88, 1978 .

Reiter, Marshall, Arthur J., Shearer, Charles. Geothermal Characteristics of the Rio Grande Rift within the southern Rocky Mountain Complex, in "Rlo Grande Rift: Tectonies and Magnetism," American Geophysical Union, Washington, DC. Reicker, Robert E., ed. 1979.

Sanford, A. R. and others. Geophysical Evidence for a Magma Body in the Crust in the vicinity of Socorro, New Mexico, in "The Earths Crust," Heacock J. S. ed. American Geophysical Union Geophysical Monograph 20, p 385-403, 1977.

Swanberg, Chandler A. Detection of Geothermal Components in Groundwaters of Dona Ana County, Southern Rio Grande Rift, New Mexico, N. M. Geol. Soc. Guidebook, 26th Fld Conf.. Las Cruces County, 1975.

Thompson, J. M. "Selecting and Collecting Thermal Springs for Chemical Analysis: A Method for Field Personnel," U. S. Dept. of the Interior Geological Survey Open-file Report (not edited). 


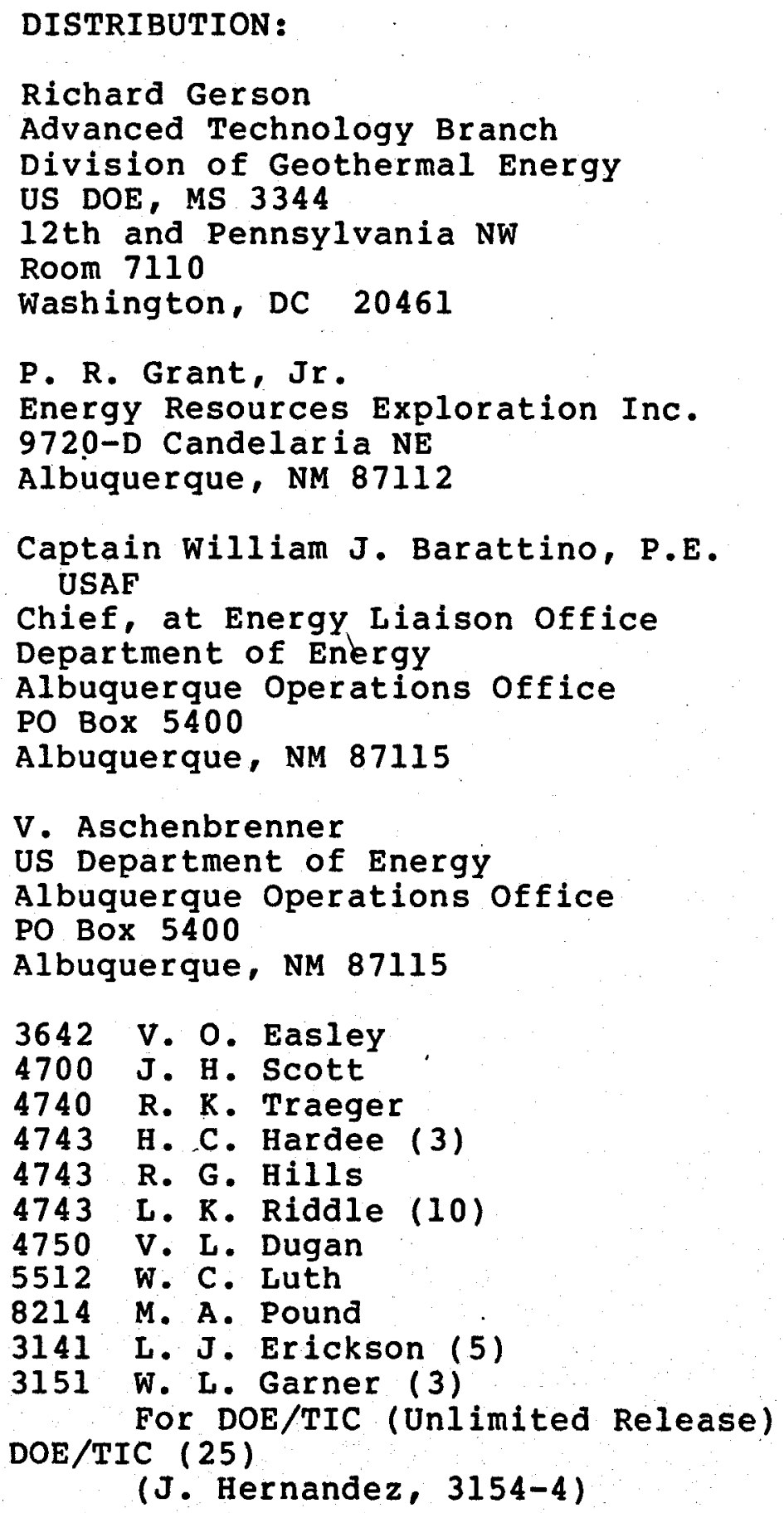


-

. 